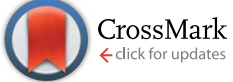

Cite this: RSC Adv., 2015, 5, 64566
Received 20th May 2015

Accepted 20th July 2015

DOI: $10.1039 / \mathrm{c} 5 \mathrm{ra09508e}$

www.rsc.org/advances

\section{A facile synthesis and evaluation of new biomolecule-based coumarin-thiazoline hybrids as potent anti-tubercular agents with cytotoxicity, DNA cleavage and $X$-ray studiest:}

\author{
Dinesh S. Reddy, ${ }^{a}$ Kallappa M. Hosamani, ${ }^{\text {aa }}$ Hirihalli C. Devarajegowda ${ }^{b}$ \\ and Mahantesh M. Kurjogi ${ }^{\mathrm{C}}$
}

An efficient and rapid synthesis of coumarin-thiazoline hybrids (1a-1j) under microwave irradiation is described with high yields. The synthesized compounds were characterized using elemental and spectroscopic analysis; in addition, the structures of compounds $1 \mathrm{a}, 1 \mathrm{~b}, 1 \mathrm{e}$ and $1 \mathrm{~h}$ have been elucidated using single crystal X-ray diffraction techniques. All the newly synthesized compounds were screened for their in vitro anti-tubercular activity and in a DNA cleavage study, while the most active compounds were subjected to a cytotoxicity assay on Vero cell lines. Among those tested, compound $1 \mathrm{~b}$ exhibited excellent anti-tubercular activity (MIC $0.09 \mu \mathrm{g} \mathrm{m}^{-1}$ ) with a low level of cytotoxicity, suggesting that compound $1 \mathrm{~b}$ is a promising lead for subsequent investigations in search of new anti-tubercular agents. Furthermore, a DNA cleavage study using an agarose gel electrophoresis method revealed that compounds $1 \mathrm{~b}, 1 \mathrm{~d}, 1 \mathrm{f}$ and $1 \mathrm{i}$ cleaved DNA more efficiently and thereby exhibit nuclease activity.

\section{Introduction}

Today, classic drug development works with small, chemically manufactured active substance molecules, since these molecules can reach almost any desired destination in the body and their small structure and chemical composition often helps them to easily penetrate cell membranes and thereby increases the bioavailability of the compound. ${ }^{1}$ Hence the majority of pharmaceuticals and biologically active drugs are all smallsized molecules. Based on these facts, medicinal chemist Christopher Lipinski and his colleagues, in the year 1997, analyzed the physicochemical properties of more than 2000 drugs and candidate drugs in clinical trials, and concluded that a compound is more likely to be membrane permeable and easily absorbed by the body if it matches the Rule of Five (RO5). ${ }^{2}$ The rules, based on the 90 percentile values of the analysed

${ }^{a}$ P. G. Department of Studies in Chemistry, Karnatak University, Dharwad-580003, India. E-mail: dr_hosamani@yahoo.com; Fax: +91-836-2771275, +91-836-2747884; Tel: +91-836-2215286

${ }^{b}$ Department of Physics, Yuvaraja's College, University of Mysore, Mysore-570005, India

${ }^{c}$ P. G. Department of Studies in Microbiology \& Biotechnology, Karnatak University, Dharwad-580003, India

$\dagger$ This research paper is dedicated to our beloved Prof. M. V. Kulkarni on his $60^{\text {th }}$ birthday.

\$ Electronic supplementary information (ESI) available. CCDC 897299, 897300, 1059231 and 1059232. For ESI and crystallographic data in CIF or other electronic format see DOI: 10.1039/c5ra09508e drugs' property distributions, apply only to absorption by passive diffusion of the compound through cell membranes; compounds that are actively transported through cell membranes by transporter proteins are exceptions to the rule. Furthermore, candidate drugs that conform to the RO5 tend to have lower attrition rates during clinical trials and hence have an increased chance of reaching the market. ${ }^{3}$ Hence, keeping these factors in view the architecture of the compounds was designed and their physicochemical properties (RO5) were analyzed which are listed below.

- All the newly synthesized compounds' molecular weights fall below the 500 daltons limit.

- The compound's lipophilicity, expressed as a quantity known as $\log P$, is less than $5(\log P$ values of all the compounds were calculated using http://www.molinspiration.com) and the values are given in Table 2 .

- The number of groups in the molecule that can donate hydrogen atoms to hydrogen bonds is less than 5 (expressed as the sum of OHs and NHs).

- The number of groups that can accept hydrogen atoms to form hydrogen bonds is less than 10 (estimated by the sum of Os and Ns).

From the results, it is clear that none of the compounds violate the rules and they fall well within the range as stated by the RO5 to qualify as a drug candidate.

Coumarins are an elite class of oxygen-containing fused heterocycles, which are widely distributed in nature, especially in plants. They form a large class of important lactones with a 
fused structure of benzene and an $\alpha$-pyrone ring, and virtually contain a $\pi-\pi$ conjugated system rich in electrons and with good charge transport properties. Moreover, the unique structure of coumarin has a special ability which allows its derivatives to readily interact with a diversity of enzymes and receptors in organisms through weak bond interactions and thereby exhibit wide potential as medicinal drugs. Hence, coumarin based compounds have attracted special interest in the area of medicinal chemistry and their outstanding contributions in the prevention and treatment of numerous diseases have become an extremely attractive highlight. ${ }^{4}$ Recently many coumarin scaffolds have been investigated as potential candidates for the treatment of tuberculosis, e.g. diaryl coumarin (1, Fig. 1), 4-aryl/ alkyl sulfonyl methyl coumarin (2), iodinated-4-aryloxymethyl coumarin (3) and chalconated coumarin (4) have been reported to exhibit potent anti-tubercular activity with MICs of 0.24 , $0.78,1.56$ and $3.5 \mu \mathrm{g} \mathrm{ml} \mathrm{m}^{-1}$ respectively, ${ }^{5}$ whereas naturally occurring coumarins such as ferulenol (5), suberosin (6), osthol (7), scopoletin (8) and umbelliferone (9) have exhibited MICs of $2,16,32,42$ and $58.3 \mu \mathrm{g} \mathrm{ml}^{-1}$ respectively. ${ }^{6}$ Reports have also suggested that the coumarin class of compounds targets the fatty acyl-ACP synthetase activity of the FadD32 enzyme ${ }^{5 a, 6 a}$ which is essential for $M t b$ survival as it plays a critical role in the biosynthesis of the unique branched fatty acids (mycolic acids) that make up the $M t b$ cell wall. Hence looking into the biological significance of coumarins, particularly in the field of tuberculosis, we anticipate that coumarins could be a good starting point for the development of new lead anti-tubercular drugs. Fig. 1 represents the structures of some potent coumarin scaffolds exhibiting anti-tubercular properties.

Thiazoline (partially reduced thiazole) is a heterocyclic compound containing both sulfur and nitrogen in the ring. It is a structural segment of various cyclopeptide alkaloids extracted from different marine organisms. ${ }^{7}$ Lissoclinamide (1, Fig. 2), patellins (2), tawicyclamides (3), bistratamides (4), and trunkamides (5) were extracted from Lissoclinum patella, whereas dolastatin E (6) and apratoxins (7) were isolated from Dolabella auricularia and Lyngbya majuscula ${ }^{8}$ respectively. Reports have shown that lissoclinamide (1) having two thiazoline rings was found to be the most cytotoxic when tested with human fibroblasts, bladder carcinoma cell lines, and normal lymphocytes $\left(\mathrm{IC}_{50}<0.1 \mu \mathrm{g} \mathrm{ml}{ }^{-1}\right),{ }^{9}$ whereas trunkamide (5) was reported to have promising antitumor activity ${ }^{\mathbf{1 0}}$ (Fig. 2).

Recently, many research groups have paid attention to the chemical properties of thiazolines, mainly due to the unique properties of the sulfur and nitrogen. The derivatives are often bioactive, exhibiting interesting biological activities like antimicrobial, anti-inflammatory, anticancer and anti-HIV activity, pheromone activity and cell division inhibition, ${ }^{\mathbf{1 1 - 1 6}}$ while small molecular mass thiazolines have found applications in the food and flavor industries. ${ }^{17}$ However, it's surprising that thiazolines have not been much explored in the field of tubercular activity though they have been found to be good antibiotics. ${ }^{18}$ Hence, looking into the biological significance of thiazoline particularly in the field of antibiotics, it was desirable for us to introduce thiazoline into the sub-substructure of the compounds by conjugating different coumarin derivatives with thiazoline;

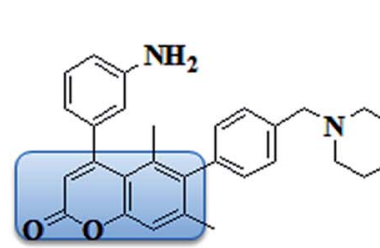

(1) Diaryl coumarin $\mathrm{MIC}=0.24 \mu \mathrm{g} / \mathrm{ml}$
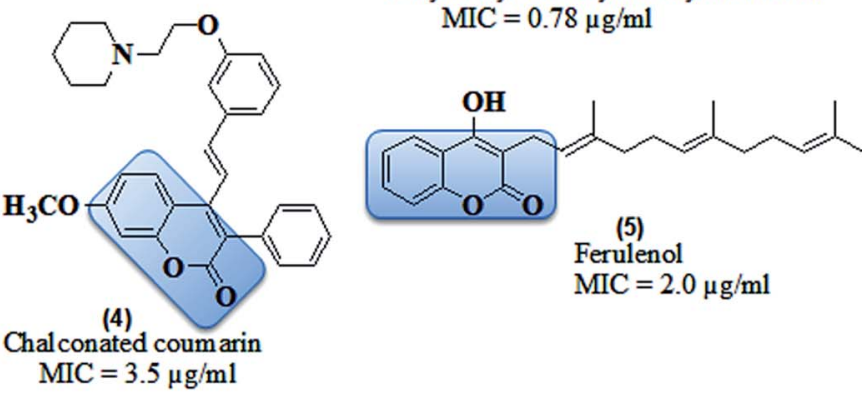

Ferulenol $\mathrm{MIC}=2.0 \mu \mathrm{g} / \mathrm{ml}$

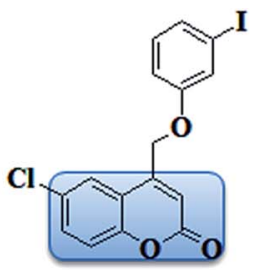

(3)

Iodinated-4-aryloxymethyl coumarin $\mathrm{MIC}=1.56 \mu \mathrm{g} / \mathrm{ml}$

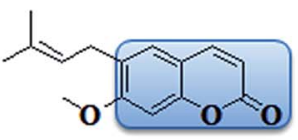

(6)

Suberosin

$\mathrm{MIC}=16 \mu \mathrm{g} / \mathrm{ml}$
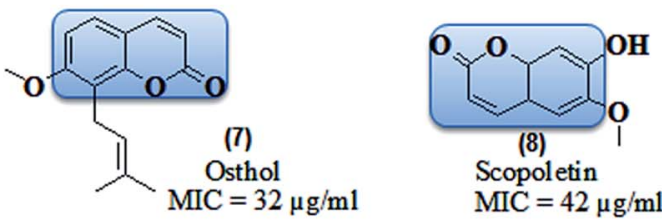

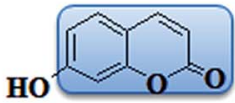

(9)

Umbelliferone

$\mathrm{MIC}=58.3 \mu \mathrm{g} / \mathrm{ml}$

Fig. 1 Synthetic and natural occurring coumarin derivatives exhibiting anti-tubercular properties. 

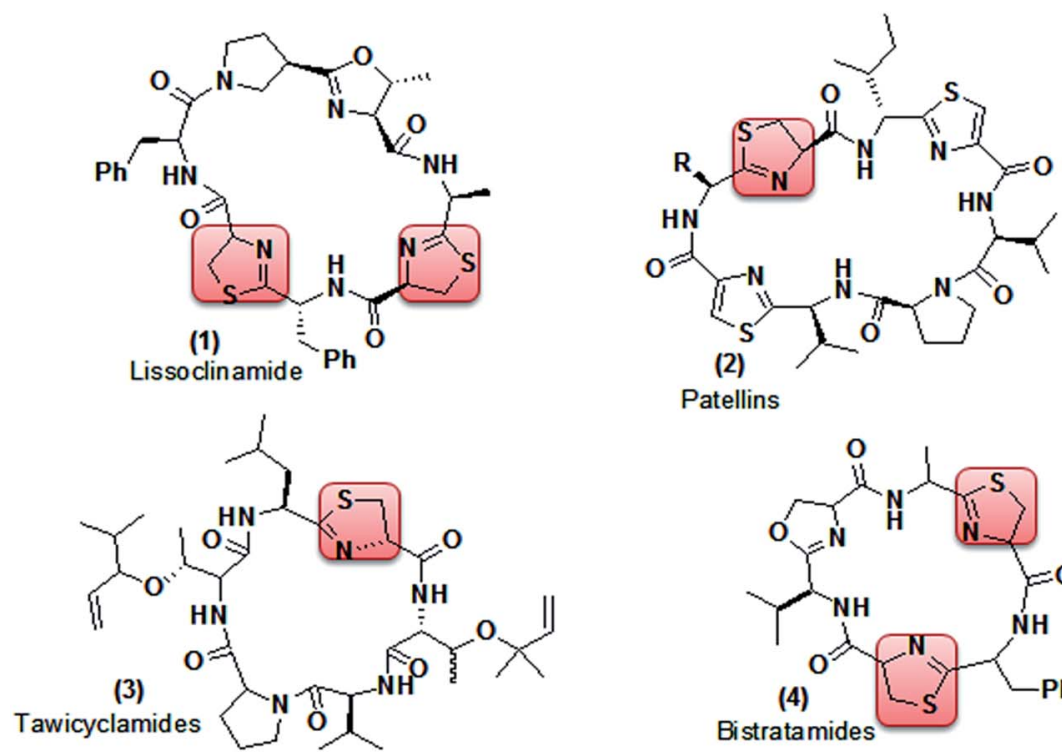

Patellins
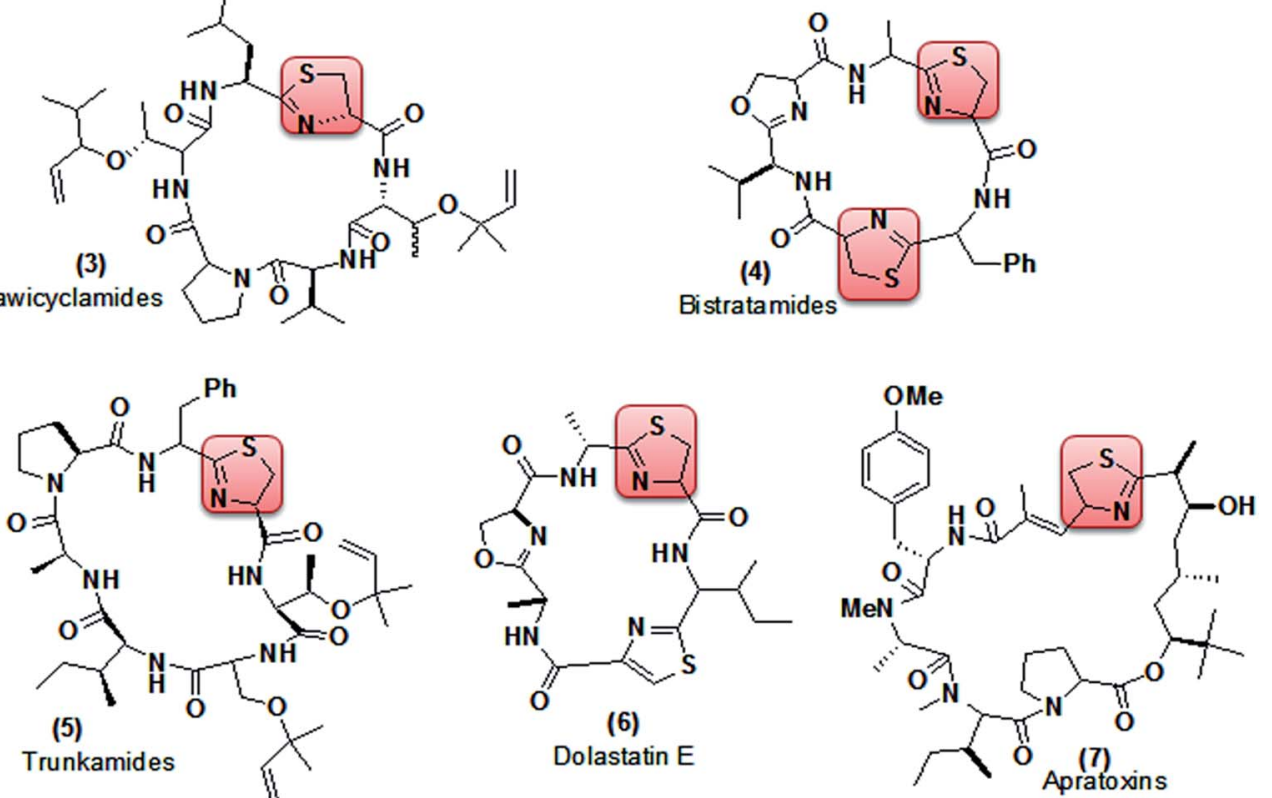

Fig. 2 Cyclopeptide alkaloids containing thiazoline as a structural segment.

since the conjugation of coumarin derivatives with various bioactive molecules such as resveratrol, tacrine, thiazolpyrazole, triazole, chalcone and pyrimidine has produced novel hybrid molecules, which are endowed with vasorelaxant, platelet anti-aggregating, Alzheimer's disease treatment, antimicrobial, antioxidant, Hsp90 C-terminal inhibitor, antioxidant, trypanocidal and anti-cancer properties. ${ }^{19}$ Furthermore, hybridized compounds have diverse or dual modes of action, multiple biological activities, modified selectivity profiles and reduced undesired side effects. Such molecules may be further modified to exhibit favorable pharmacokinetics and oral bioavailability. ${ }^{20}$

Thioether linkages are present in many bioactive natural and pharmaceutical products. However it's surprising that in comparison to the amount of effort devoted to the discovery of new methods for preparing $\mathrm{C}-\mathrm{C}, \mathrm{C}-\mathrm{O}$, and $\mathrm{C}-\mathrm{N}$ bonds, considerably less resources have been allocated to the development of preparing C-S bonds. ${ }^{21}$ In fact, it has been demonstrated in several instances that replacing a carbon or oxygen atom with sulfur greatly enhances the bioactivity of certain compounds with respect to their oxygenated or carbon counterparts. ${ }^{22}$ For example, SAR studies have shown that for diallyl sulfide, which exhibits potent anticancer properties, ${ }^{22}$ a single sulfur atom bonded to at least one allyl side chain is required for inhibition of carcinogenesis. ${ }^{23}$ A number of drugs, which are applied for the treatment of Alzheimer's disease, Parkinson's disease, and diabetes, as well as immune and inflammatory diseases, carry aryl sulfide moieties on their backbone unit. ${ }^{24}$ Furthermore, the thioether linkage has provided compounds with diverse antagonistic properties against the histamine H2receptor, e.g. cimetidine ${ }^{25}$ (Tagamet) (1), famotidine ${ }^{26}$ (Pepcid) (2), and ranitidine ${ }^{27}$ (Zantac) (3) are being used to treat and prevent ulcers; the thioether linkage in an immunity-related conjugate between doxorubicin and the monoclonal antibody BR96 was demonstrated to be critical to its antitumor proper$\operatorname{ties}^{28}(4)$; and meropenem ${ }^{29}(5)$ has been used as an antibiotic drug (Fig. 3). Hence, it is apparent that the development of novel thioethers, and more generally, $\mathrm{C}-\mathrm{S}$ bonds, would be of great benefit to both chemists and biologists for developing potent drugs.

Hence, motivated by the inherent biological relevance of coumarin, thiazoline, and thioether, the present investigation pertains to the hybridization of two active pharmacophores (coumarin \& thiazoline) via a thioether linkage. It is expected that the additive effect of this combination might produce a synergetic effect in enhancing the bio-activity of the compound. 


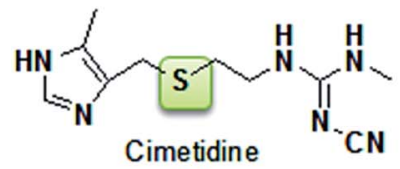

(1)
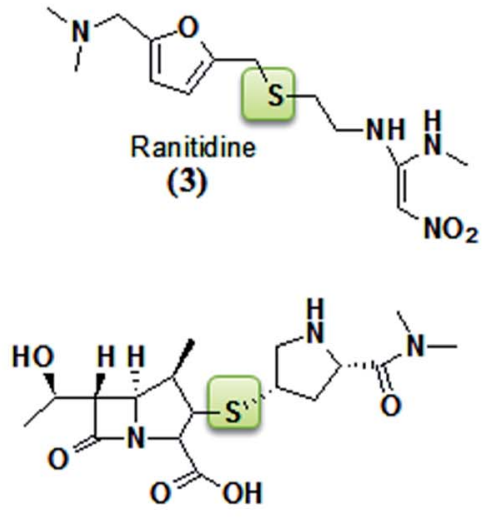

Meropenem

(5)<smiles>NC(N)=Nc1nc(C[SH]2CC3CCC(C3)C2)cs1</smiles>

(2)

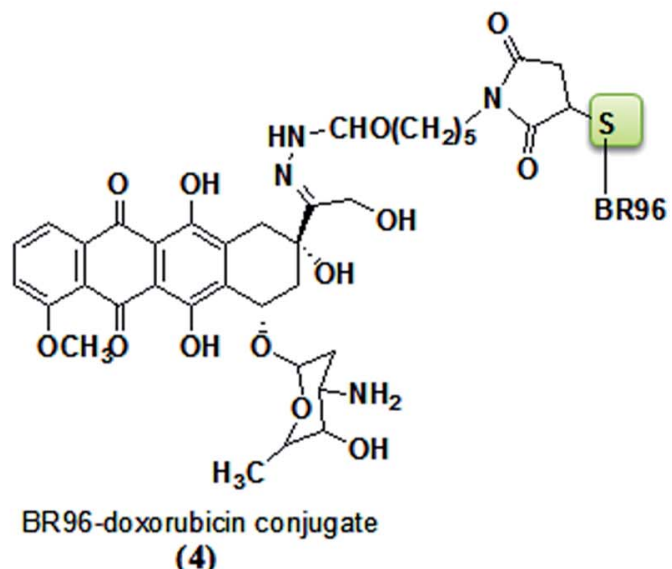

Fig. 3 Bioactive thioether linked compounds.

The designed hypothetical interaction model is represented in (Fig. 4). To further our continued effort towards the development of microwave assisted synthetic methodologies, ${ }^{19 f, 30}$ we describe in this paper an efficient and facile synthesis of coumarin-thiazoline hybrids $(\mathbf{1 a} \mathbf{-} \mathbf{1 j})$ under microwave irradiation, through which the yields of the compounds were improved drastically in a very short reaction time as compared to conventional methods.

\section{Results and discussion}

\section{Chemistry}

The substituted 4-bromomethyl coumarins (a-j) were synthesized using a Pechman cyclisation of the phenols with 4-bromoethylacetoacetate. ${ }^{31}$ Condensation of the 4-bromomethyl coumarin $(\mathbf{a}-\mathbf{j})(0.01 \mathrm{~mol})$ with 4,5-dihydrothiazole-2-thiol (1) $(0.01 \mathrm{~mol})$ in anhydrous $\mathrm{K}_{2} \mathrm{CO}_{3}(0.03 \mathrm{~mol})$ using absolute ethanol as the solvent afforded 4-[(4,5-dihydro-1,3-thiazol-2ylthio)methyl]substituted-2 $H$-chromen-2-one derivatives $(\mathbf{1 a}-\mathbf{1 j})$

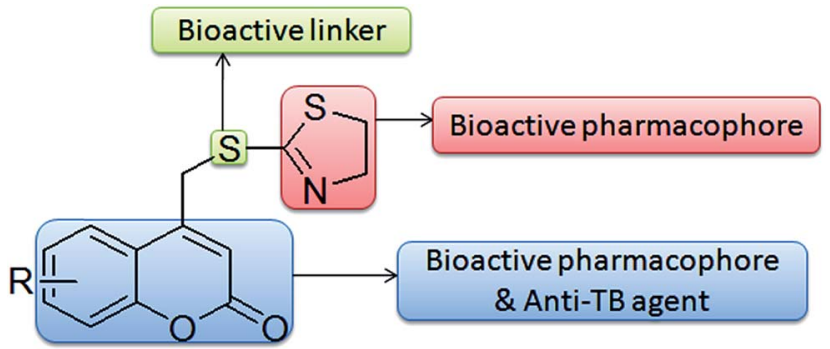

Fig. 4 Design strategy to enhance anti-tubercular activity (hypothetical interaction model). under both conventional and microwave irradiation methods. Synthesis of the target compounds was carried out as outlined in Scheme 1. From the results, it is clear that the microwave approach proved to be extremely fast, providing good to excellent yields (81-91\%) as compared to the conventional method (61-75\%). Here the most noticeable advancement was the speed with which the reactions were completed i.e. within 5-9 minutes, which is $90-120$ times faster than the conventional method. The results are summarized in Table 1.

All the newly synthesized compounds were characterized using FTIR, ${ }^{1} \mathrm{H}$ NMR, ${ }^{13} \mathrm{C}$ NMR, mass and elemental analysis. The spectral data of the newly synthesized compounds $(\mathbf{1} \mathbf{a}-\mathbf{1} \mathbf{j})$ are provided in the experimental section, and are in accordance with the assigned structures of the compounds. The ${ }^{1} \mathrm{H}$ and ${ }^{13} \mathrm{C}$ NMR spectra of all the compounds are given in the ESIt and are in good agreement with the proposed structure of the compounds. In the case of compound $1 \mathrm{a}\left(\mathrm{R}=6 \mathrm{CH}_{3}\right)$, the IR spectrum exhibited two characteristic bands at $1713 \mathrm{~cm}^{-1}$ for the lactone of the coumarin and $1574 \mathrm{~cm}^{-1}$ for the imine of the thiazoline moiety. The formation of the product was established using the ${ }^{1} \mathrm{H}$ NMR spectrum, wherein a sharp singlet at $\delta 4.45$ ppm corresponds to the $-\mathrm{CH}_{2}-\mathrm{S}$, confirming the formation of the condensed product via thioether linkage, and the presence of two triplets at $\delta 3.45 \mathrm{ppm}$ and $\delta 4.23 \mathrm{ppm}$ corresponds to the $=\mathrm{N}-\mathrm{CH}_{2}$ and $-\mathrm{S}-\mathrm{CH}_{2}$ of the thiazoline ring respectively. Two singlets were observed in the aromatic region at $\delta 6.56$ and $\delta$ $7.40 \mathrm{ppm}$, corresponding to the $\mathrm{C}_{3}-\mathrm{H}$ and $\mathrm{C}_{5}-\mathrm{H}$ of the coumarin moiety respectively, whereas the $\mathrm{C}_{7}-\mathrm{H}$ and $\mathrm{C}_{8}-\mathrm{H}$ of the coumarin resonate as doublets at $\delta 7.24$ and $\delta 7.34 \mathrm{ppm}$ respectively, while the methyl protons were observed as a singlet at $\delta 2.42 \mathrm{ppm}$ which corresponds to the $\mathrm{C}_{6}-\mathrm{CH}_{3}$ of the coumarin. The ${ }^{13} \mathrm{C}$ NMR spectrum provides additional support 


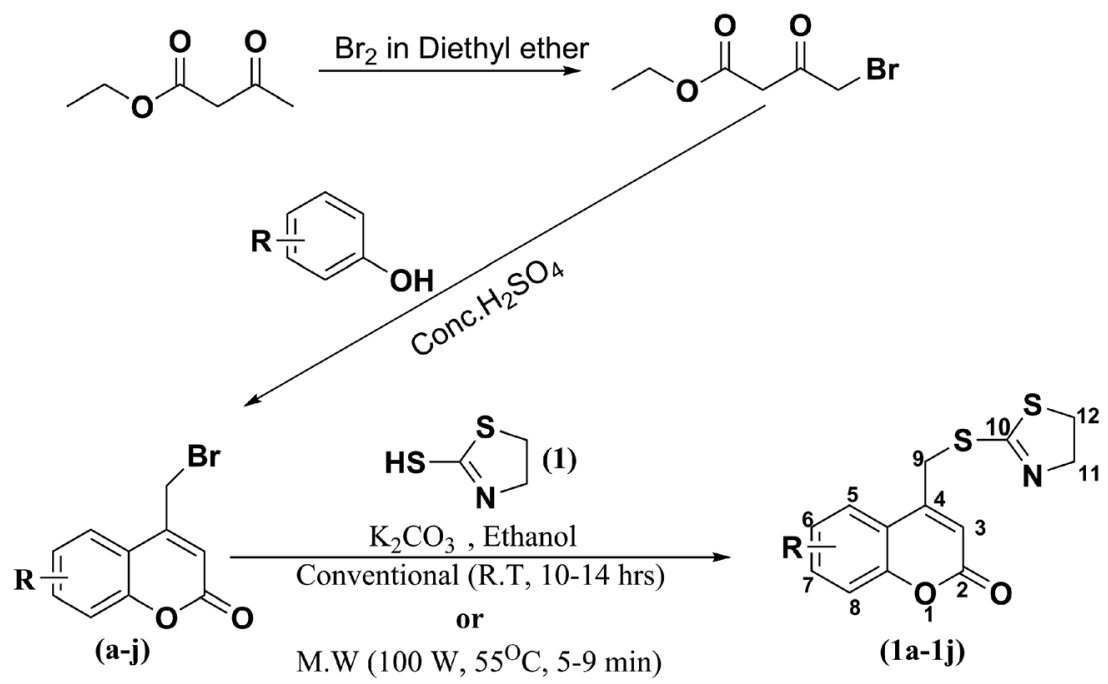

Scheme 1 Synthetic route to synthesize the title compounds (1a-1j).

Table 1 Comparison between the conventional and microwave irradiation methods

\begin{tabular}{|c|c|c|c|c|c|}
\hline \multirow[b]{2}{*}{ Product } & \multirow[b]{2}{*}{$\mathrm{R}$} & \multicolumn{2}{|c|}{ Yield (\%) } & \multicolumn{2}{|c|}{ Time (min) } \\
\hline & & $\mathrm{C}^{a}$ & $\mathbf{M}^{b}$ & $\mathrm{C}$ & M \\
\hline $1 \mathrm{a}$ & $6-\mathrm{CH}_{3}$ & 63 & 88 & 600 & 5 \\
\hline $1 b$ & $6-C l$ & 71 & 83 & 630 & 7 \\
\hline $1 c$ & 6- $\mathrm{OCH}_{3}$ & 75 & 91 & 670 & 6 \\
\hline 1d & 5,6-Benzo & 64 & 82 & 810 & 8 \\
\hline $1 e$ & $7-\mathrm{CH}_{3}$ & 66 & 86 & 640 & 6 \\
\hline 1f & 7-Cl & 68 & 84 & 650 & 7 \\
\hline $1 \mathrm{~g}$ & $7-\mathrm{OCH}_{3}$ & 69 & 87 & 720 & 6 \\
\hline $1 \mathrm{~h}$ & $5,7-\mathrm{diCH}_{3}$ & 61 & 81 & 840 & 9 \\
\hline $1 \mathbf{i}$ & $6-B r$ & 64 & 88 & 730 & 8 \\
\hline $1 \mathrm{j}$ & $7-B r$ & 62 & 87 & 720 & 8 \\
\hline
\end{tabular}

${ }^{a} \mathrm{C}$ - conventional. ${ }^{b} \mathrm{M}-$ microwave.

for the structure of the compound (1a), wherein the lactone carbonyl resonated at $\delta 160.73 \mathrm{ppm}$, the thioether linked -S$\mathrm{CH}_{2}$ resonated at $\delta 36.10 \mathrm{ppm}$, and the $-\mathrm{C}=\mathrm{N}$ of the imine resonated at $\delta 163.59 \mathrm{ppm}$, whereas the $-\mathrm{S}-\mathrm{CH}_{2}$ and $=\mathrm{N}-\mathrm{CH}_{2}$ corresponding to the thiazoline ring resonated at $\delta 32.06 \mathrm{ppm}$ and $\delta 63.89 \mathrm{ppm}$ respectively, and the methyl carbon resonated at $\delta 21.03 \mathrm{ppm}$ which corresponds to the $\mathrm{C}_{6}-\mathrm{CH}_{3}$ of the coumarin. The molecular ion peak at $291[\mathrm{M}]^{+}$in the GC-MS spectrum confirmed the proposed structure for compound $\mathbf{1 a}$. The rest of the compounds gave satisfactory analytical and spectroscopic data which were in accordance with their assigned structures.

\section{X-ray diffraction analysis}

Single crystals for compounds $\mathbf{1 a}, \mathbf{1 b}, \mathbf{1 e}$ and $\mathbf{1 h}$ were developed by slow evaporation of chloroform at room temperature. Compounds 1a, $\mathbf{1 b}$ and $\mathbf{1 e}$ crystallized under a triclinic system with the space group $P \overline{1}$ and compound $\mathbf{1 h}$ under a monoclinic system with the space group $P 2_{1} / c$. The unit cell dimensions for compound 1a are as follows: $a=7.93370(10) \AA, b=8.09230(10)$ $\AA, c=10.7299(2) \AA, \alpha=99.1900(10)^{\circ}, \beta=92.5250(10)^{\circ}, \gamma=$ $96.4970(10)^{\circ}, Z=2$. For compound $1 \mathrm{~b}$ the unit cell dimensions are: $a=7.3443(3) \AA, b=7.7814(3) \AA, c=12.6804(4) \AA, \alpha=$ $85.486(2)^{\circ}, \beta=82.226(2)^{\circ}, \gamma=65.984(2)^{\circ}, Z=2$. For compound 1e the unit cell dimensions are: $a=7.8774(2) \AA, b=8.4986(3) \AA$, $c=11.2330(3) \AA, \alpha=91.435(2)^{\circ}, \beta=107.376(2)^{\circ}, \gamma=$ 107.927(2) $)^{\circ}, Z=2$; whereas for compound $\mathbf{1 h}$ the unit cell dimensions were found to be: $a=7.2356(8) \AA, b=7.9426(10) \AA$, $c=25.027(3) \AA, \alpha=90^{\circ}, \beta=96.742(8)^{\circ}, \gamma=90^{\circ}, Z=4$. The structures were solved and refined using SHELXS-97. $\hbar^{32}$

$\mathrm{X}$-ray analysis for compound 1a. From the crystal data it was observed that the asymmetric unit of compound 4-[(4,5-dihydro-1,3-thiazol-2-ylthio)methyl]-6-methyl-2H-chromen-2-one

(1a) contains only one independent molecule. The crystal structure shows weak intramolecular $\mathrm{C} 16 \cdots \mathrm{H} 16 \mathrm{~B} \cdots \mathrm{N} 5$ \& $\mathrm{C} 7 \cdots$ $\mathrm{H} 7 \cdots \mathrm{S} 2$ hydrogen bonds and is further stabilized by intermolecular C15-H15C $\cdots \mathrm{S} 2$ hydrogen bonds, that generate inversion dimers with $\mathrm{R}_{2}{ }_{2}(16)$ ring motifs. The $2 H$-chromene ring systems is nearly planar, with a maximum deviation of 0.0234(17) $\AA$ for atom C9. In the crystal structure, the bond length $\mathrm{C} 17-\mathrm{S} 1=$ $1.7705(2) \AA$ is longer than the bond length of $\mathrm{C} 18-\mathrm{C} 19=$ $1.498(3) \AA$ and the bond angle C17-S1-C19 = 88.60(10 $)^{\circ}$ is less than the bond angle of $\mathrm{C} 17-\mathrm{N} 5-\mathrm{C} 18=110.45(9)^{\circ}$. As a result of these differences in the molecular parameters, the thiazoline ring adopts a nearly twisted form conformation. The dihedral angle between the $2 H$-chromene ring (O3/C6-C14) and the thiazoline ring $(\mathrm{N} 5 / \mathrm{S} 1 / \mathrm{C} 17-\mathrm{C} 19)$ is $82.72(10)^{\circ}$. The packing of the crystal structure is stabilized by C19-H19A $\cdots \pi \mathrm{Cg}$ (3) (C9C14) interactions as well as $\pi-\pi[\mathrm{Cg}(2)(\mathrm{O} 3 / \mathrm{C} 6-\mathrm{C} 10) \cdots \mathrm{Cg}(3)$ (C9$\mathrm{C} 14)]$ interactions between the fused benzene and the pyrone ring of the coumarin moieties [shortest centroid-centroid distance $=3.6368(10) \AA]$. The packing of the molecules exhibited layered stacking when viewed down the $a$-axis. These layers are linked via hydrogen bonds, which in turn form a linear polymeric chain. The X-ray structure parameters and refinement for compound (1a) are presented in Table 2. The 
ORTEP and packing diagrams of compound $\mathbf{1 a}$ are portrayed in Fig. 5.

X-ray analysis for compound $\mathbf{1 b}$. From the crystal data it is known that the asymmetric unit of 6-chloro-4-[(4,5-dihydro-1,3thiazol-2-ylthio)methyl]-2 $H$-chromen-2-one (1b) contains only one independent molecule. The crystal structure shows weak intramolecular $\mathrm{C} 8 \cdots \mathrm{H} 8 \cdots \mathrm{S} 3$ and $\mathrm{C} 16 \cdots \mathrm{H} 16 \mathrm{~B} \cdots \mathrm{N} 6$ and intermolecular $\mathrm{C} 16 \cdots \mathrm{H} 16 \mathrm{~A} \cdots \mathrm{O} 5$ hydrogen bonds and is further stabilized by intermolecular $\mathrm{C} 16-\mathrm{H} 16 \mathrm{~B} \cdots \mathrm{Cl} 1$ hydrogen bonds, that generate inversion dimers with $\mathrm{R}_{2}^{2}(14)$ ring motifs. The $2 H$ chromene ring (O4/C7-C15) system is nearly planar, with a maximum deviation of $0.0202(23) \AA$ for atom C13. In the crystal structure, the bond length $\mathrm{C} 17-\mathrm{S} 2=1.7595(2) \AA$ is longer than the bond length of $\mathrm{C} 18-\mathrm{C} 19=1.495(4) \AA$ and the bond angle $\mathrm{C} 17-\mathrm{S} 2-\mathrm{C} 19=89.31(12)^{\circ}$ is less than the bond angle of C17$\mathrm{N} 6-\mathrm{C} 18=111.0(2)^{\circ}$. As a result of these differences in the molecular parameters, the thiazoline ring adopts a nearly twisted form conformation. The dihedral angle between the $2 \mathrm{H}$ chromene ring (O4/C7-C15) and the thiazoline (S2/N6/C17C19) ring is $89.16(11)^{\circ}$. The packing of the crystal structure is stabilized by $\pi-\pi[\mathrm{Cg}(2)(\mathrm{O} 4 / \mathrm{C} 7-\mathrm{C} 11) \cdots \mathrm{Cg}(3)(\mathrm{C} 10-\mathrm{C} 15)]$ interactions between the fused benzene and the pyrone ring of the coumarin moieties [shortest centroid-centroid distance = 3.7101 (13) ̊]. The crystal structure parameters for compound 1b are presented in Table 3. The ORTEP and packing diagrams of compound $\mathbf{1 b}$ are portrayed in Fig. 6 .

$\mathrm{X}$-ray analysis for compound 1e. From the crystal data it is known that the asymmetric unit of 4-((4,5-dihydrothiazol-2ylthio)methyl)-7-methyl- $H$-chromen-2-one (1e) contains only one independent molecule. The crystal structure shows weak intramolecular $\mathrm{C} 16 \cdots \mathrm{H} 16 \mathrm{~B} \cdots \mathrm{N} 5$ and $\mathrm{C} 7 \cdots \mathrm{H} 7 \cdots \mathrm{S} 2$ hydrogen bonds. In addition, intermolecular $\mathrm{C} 6 \cdots \mathrm{H} 6 \mathrm{C} \cdots \mathrm{N} 5$ hydrogen bonds link the components into chains along [100] and generate inversion dimers with $\mathrm{R}_{2}^{2}(22)$ ring motifs. The $2 H^{-}$ chromene ring (O3/C7-C15) system is nearly planar, with a maximum deviation of $0.0271(18) \AA$ for atom C14. In the crystal structure, the bond length $\mathrm{C} 18-\mathrm{S} 2=1.802(2) \AA$ is longer than the bond length of $\mathrm{C} 18-\mathrm{C} 19=1.522(3) \AA$ and the bond angle $\mathrm{C} 17-\mathrm{S} 2-\mathrm{C} 18=88.63(9)^{\circ}$ is less than the bond angle of C17-N5$\mathrm{C} 19=111.16(15)^{\circ}$. As a result of these differences in the

Table 2 Crystal data, data collection details and structure refinement for $1 \mathrm{a}$

\author{
Empirical formula \\ Formula weight \\ Crystal system, space group \\ Unit cell dimensions
}

\author{
Volume \\ Z \\ Calculated density \\ Crystal size \\ Absorption coefficient \\ $F(000)$ \\ Crystal form \\ Radiation source \\ Radiation type \\ Radiation monochromator \\ Criterion for observed reflection

\section{Data collection} \\ Diffractometer \\ Data collection method \\ Absorption correction \\ Theta range for data collection \\ Limiting indices \\ Reflections collected/unique \\ Completeness to theta \\ Max. and min. transmission

\section{Refinement} \\ Refinement method \\ Data/restraints/parameters \\ Goodness-of-fit on $F^{2}$ \\ Final $R$ indices $[I>2 \sigma(I)]$ \\ $R$ indices (all data) \\ Weighting scheme \\ $(\Delta / \sigma) \max$ \\ Largest diff. peak and hole
}

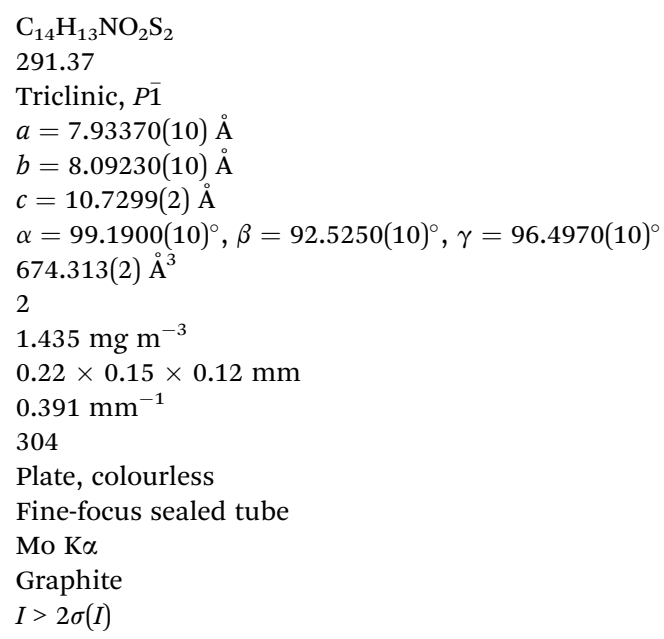

Bruker SMART CCD area-detector

$\omega-\chi$ scans

Multi-scan

1.93 to $24.99^{\circ}$

$-9 \leq h \leq 9,-9 \leq k \leq 9,-12 \leq l \leq 12$

$10734 / 2376[R($ int $)=0.0200]$

$99.6 \%$

$T_{\max }=1.000, T_{\min }=0.790$

Full-matrix least-squares on $F^{2}$

2376/0/172

1.059

$R_{1}=0.0379, \mathrm{w} R_{2}=0.1108$

$R_{1}=0.0414, \mathrm{w} R_{2}=0.1141$

$\omega=1 /\left[\sigma^{2}\left(F_{\mathrm{o}}{ }^{2}\right)+(0.068 P)^{2}+0.230 P\right]$ where $P=\left(F_{\mathrm{o}}{ }^{2}+2 F_{\mathrm{c}}{ }^{2}\right) / 3$

$<0.001$

0.356 and $-0.237 \mathrm{e} \AA^{-3}$ 



Fig. 5 ORTEP and packing diagrams for compound 1a. Displacement ellipsoids are drawn at the 50\% probability level. Hydrogen atoms are shown as spheres of arbitrary radius.

molecular parameters, the thiazoline ring adopts a nearly twisted form conformation. The dihedral angle between the $2 \mathrm{H}^{-}$ chromene ring (O3/C7-C15) and the thiazoline ring (S2/N5/ C17-C19) is $63.61(8)^{\circ}$. The crystal structure also features $\mathrm{C} \cdots$
$\mathrm{H} \cdots \pi[\mathrm{Cg}(2) ;(\mathrm{O} 3 / \mathrm{C} 10 / \mathrm{C} 11 / \mathrm{C} 13-\mathrm{C} 15)]$ and $\pi-\pi[\mathrm{Cg}(2)(\mathrm{O} 3 / \mathrm{C} 10 /$ $\mathrm{C} 11 / \mathrm{C} 13-\mathrm{C} 15) \cdots \mathrm{Cg}(3)(\mathrm{C} 7-\mathrm{C} 12)]$ interactions between the fused benzene and the pyrone ring of the coumarin moieties [shortest centroid-centroid distance $=3.7698(9) \AA]$ and shows stacking

Table 3 Crystal data, data collection details and structure refinement for $1 \mathrm{~b}$

Empirical formula

Formula weight

Temperature

Wavelength

Crystal system, space group

Unit cell dimensions

Volume

$Z$

Calculated density

Crystal size

Absorption coefficient

$F(000)$

Crystal form

Radiation source

Radiation type

Radiation monochromator

Criterion for observed reflection

\section{Data collection}

Diffractometer

Data collection method

Absorption correction

Theta range for data collection

Limiting indices

Reflections collected/unique

Completeness to theta

Max. and min. transmission

\section{Refinement}

Refinement method

Data/restraints/parameters

Goodness-of-fit on $F^{2}$

Final $R$ indices $[I>2 \sigma(I)]$

$R$ indices (all data)

Weighting scheme

$(\Delta / \sigma) \max$

Largest diff. peak and hole

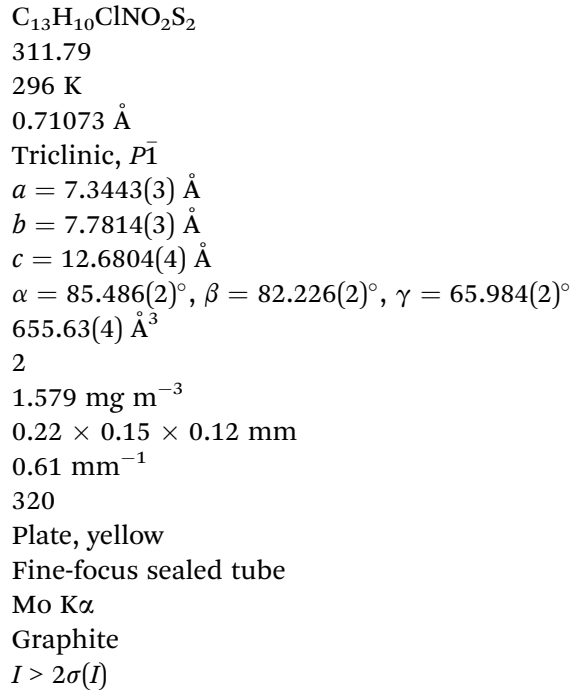

Bruker SMART CCD area-detector

$\omega-\chi$ scans

Multi-scan

1.62 to $24.99^{\circ}$

$-8 \leq h \leq 8,-9 \leq k \leq 9,-15 \leq l \leq 15$

$9894 / 2307[R(\mathrm{int})=0.0252]$

$99.8 \%$

$T_{\max }=1.000, T_{\min }=0.790$

Full-matrix least-squares on $F^{2}$

2307/0/172

1.075

$R_{1}=0.0340, \mathrm{w} R_{2}=0.0921$

$R_{1}=0.0380, \mathrm{w} R_{2}=0.0946$

$\omega=1 /\left[\sigma^{2}\left(F_{\mathrm{o}}{ }^{2}\right)+(0.0505 P)^{2}+0.2154 P\right]$ where $P=\left(F_{\mathrm{o}}{ }^{2}+2 F_{\mathrm{c}}{ }^{2}\right) / 3$ $<0.001$

0.338 and $-0.319 \mathrm{e} \AA^{-3}$ 



Fig. 6 ORTEP and packing diagrams for compound 1b. Displacement ellipsoids are drawn at the 50\% probability level. Hydrogen atoms are shown as spheres of arbitrary radius.

when viewed along the $b$-axis. The crystal structure parameters for compound 1e are presented in Table 4. The ORTEP and packing diagrams of compound $\mathbf{1 e}$ are portrayed in Fig. 7.

$\mathrm{X}$-ray analysis for compound $\mathbf{1 h}$. From the crystal data it is known that the asymmetric unit for compound 4-((4,5-dihydrothiazol-2-ylthio)methyl)-5,7-dimethyl-2 $H$-chromen-2-one

(1h) is characterized by a long range, well defined three dimensional order. The asymmetric unit contains only one independent molecule as depicted in Fig. 8. The $2 H$-chromene ring (O3/C11/C12/C14-C16) system is nearly planar, with a maximum deviation of $0.0162(13) \AA$ for atom $\mathrm{C} 13$, and in the crystal structure, the bond length $\mathrm{C} 20-\mathrm{S} 2=1.802(6) \AA$ is longer than the bond length of $\mathrm{C} 19-\mathrm{C} 20=1.509(8) \AA$ and the bond angle $\mathrm{C} 18-\mathrm{S} 2-\mathrm{C} 20=88.0(3)^{\circ}$ is less than the bond angle of C18$\mathrm{N} 5-\mathrm{C} 19=109.6(5)^{\circ}$. As a result of these differences in the molecular parameters, the thiazoline ring adopts a nearly twisted form conformation. The dihedral angle between the $2 \mathrm{H}$ chromene ring and the thiazoline ring ( $22 / \mathrm{N} 5 / \mathrm{C} 18-\mathrm{C} 20)$ is 8.1(3) $)^{\circ}$ The crystal structure contains weak intramolecular $\mathrm{C} 15 \cdots \mathrm{H} 15 \cdots \mathrm{S} 1$ hydrogen bonds. In addition, intermolecular $\mathrm{C} 13 \cdots \mathrm{H} 13 \cdots \mathrm{O} 4$ hydrogen bonds link the components into chains along [010] and generate inversion dimers with $\mathrm{R}_{2}^{2}(12)$ ring motifs. The crystal structure also features $\mathrm{C} 7 \cdots \mathrm{H} 7 \mathrm{~B} \cdots \pi$ $[\mathrm{Cg}(3) ;(\mathrm{C} 8-\mathrm{C} 13)]$ and $\pi-\pi[\mathrm{Cg}(2)(\mathrm{O} 3 / \mathrm{C} 11 / \mathrm{C} 12 / \mathrm{C} 14-\mathrm{C} 16) \cdots \mathrm{Cg}(3)$ (C8-C13)] interactions between the fused benzene and the pyrone ring of the coumarin moieties [shortest centroidcentroid distance $=3.568(3) \AA]$ and shows stacking when viewed along the $c$-axis. The crystal structure parameters for compound $\mathbf{1 h}$ are presented in Table 5. The ORTEP and packing diagrams of compound $\mathbf{1 h}$ are portrayed in Fig. 8.

\section{Bioevaluation}

The synthesized compounds were screened for their potential in vitro anti-tubercular activity using a Microplate Alamar Blue Assay (MABA $)^{33}$ and in a CT-DNA cleavage study using a gel electrophoresis method. ${ }^{34}$ Furthermore, the most active compounds were tested for their cytotoxicity against Vero cells using a $\mathrm{MTT}^{35}$ assay.
Anti-tubercular activity. All the compounds (1a-1j) were initially screened at a single concentration of $6.25 \mu \mathrm{g} \mathrm{ml}$ against $\mathrm{MtbH}_{37} \mathrm{Rv}$ (ATCC-27294) in BACTEC 12 B medium, using a Microplate Alamar Blue Assay (MABA). The results are summarized in Table 6 . Compounds exhibiting $\geq 90 \%$ inhibition in the initial screening were tested at and below $6.25 \mu \mathrm{g}$ $\mathrm{ml}^{-1}$ using 2-fold dilution to determine the actual MIC. The results of the anti-tubercular studies are presented in Table 6. In the primary screening, most of the compounds displayed 91$98 \%$ inhibition. In the secondary level of screening, four compounds (1b, 1f, $\mathbf{1 i}$ and $\mathbf{1 j}$ ) inhibited $M t b$ with a MIC $<1 \mu \mathrm{g}$ $\mathrm{ml}^{-1}$ and two compounds (1a and 1c) had a MIC $<4 \mu \mathrm{g} \mathrm{ml} l^{-1}$, compared to isoniazid (MIC: $0.02 \mu \mathrm{g} \mathrm{ml}^{-1}$ ). From Table 6, it is clear that the halogen $(-C l$ and $-B r)$ substituted compounds $(\mathbf{1 b}$, 1f, 1i and 1j) have shown more significant anti-tubercular

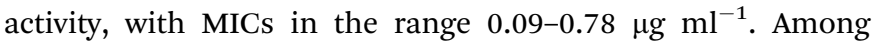
them, compounds $\mathbf{1 b}$ and $\mathbf{1 i}$ exhibited the most pronounced anti-tubercular activity with a MIC of 0.09 and $0.19 \mu \mathrm{g} \mathrm{ml}^{-1}$ respectively. In particular, compound $\mathbf{1 b}$ was found to be the most active in vitro with a MIC of $0.09 \mu \mathrm{g} \mathrm{ml}{ }^{-1}$. Whereas compounds 1a and 1c exhibited comparatively good activity with a MIC 1.56 and $3.12 \mu \mathrm{g} \mathrm{m} \mathrm{ml}^{-1}$ respectively, while compounds $1 \mathrm{e}$ and $\mathbf{1 g}$ showed moderate inhibition against $\mathrm{Mtb}$ with similar MIC values of $6.25 \mu \mathrm{g} \mathrm{ml}{ }^{-1}$. The remaining compounds $\mathbf{1 d}$ and $\mathbf{1 h}$ were found to be ineffective against the $\mathrm{MtbH}_{3} \mathrm{Rv}$ strain. Although from Table 6, no clear relation was observed between the MIC and the lipophilicity (calculated $\log P)$.

Having identified a good number of active antimycobacterial compounds (1a, 1b, 1c, 1e, 1f, $1 \mathbf{g}, \mathbf{1 i}$ and $\mathbf{1 j})$ the next step was to examine their toxicity against the Vero cell line, at a concentration 10 times their actual MIC value. A compound is considered toxic if it causes over $50 \%$ inhibition of normal cells at a concentration 10 fold higher than its MIC. ${ }^{36}$ From the results (Table 6), it is clear that the tested compounds exhibited moderate to low levels of cytotoxicity with a percentage survival of the Vero cells in the range of 61 to $94 \%$, and none of the tested compounds exhibited any significant cytotoxic effects on the 
Table 4 Crystal data, data collection and structure refinement (1e)

Empirical formula

Formula weight

Temperature

Wavelength

Crystal system, space group

Unit cell dimensions

Volume

$Z$

Calculated density

Crystal size

Absorption coefficient

$F(000)$

Crystal form

Radiation source

Radiation type

Radiation monochromator

Criterion for observed reflection

\section{Data collection}

Diffractometer

Data collection method

Absorption correction

Theta range for data collection

Limiting indices

Reflections collected/unique

Completeness to theta

Max. and min. transmission

\section{Refinement}

Refinement method

Data/restraints/parameters

Goodness-of-fit on $F^{2}$

Final $R$ indices $[I>2 \sigma(I)]$

$R$ indices (all data)

Weighting scheme

$(\Delta / \sigma) \max$

Largest diff. peak and hole

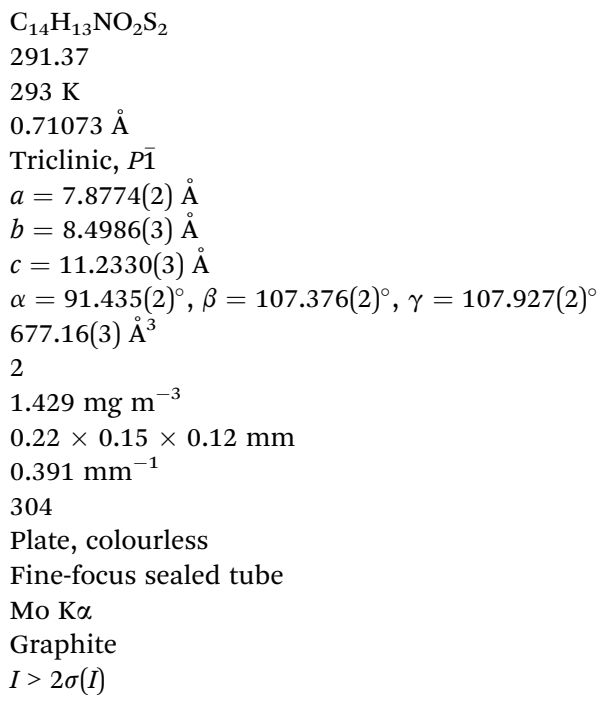

Bruker SMART CCD area-detector

$\omega-\chi$ scans

Multi-scan

1.92 to $29.02^{\circ}$

$-10 \leq h \leq 10,-11 \leq k \leq 11,-15 \leq l \leq 15$

$13042 / 3587$ [ $R($ int $)=0.0236$ ]

$99.4 \%$

$T_{\max }=1.000, T_{\min }=0.790$

Full-matrix least-squares on $F^{2}$

$3587 / 0 / 172$

1.04

$R_{1}=0.0419, \mathrm{w} R_{2}=0.1165$

$R_{1}=0.0526, \mathrm{w} R_{2}=0.1247$

$\omega=1 /\left[\sigma^{2}\left(F_{\mathrm{o}}{ }^{2}\right)+(0.0653 P)^{2}+0.1591 P\right]$ where $P=\left(F_{\mathrm{o}}{ }^{2}+2 F_{\mathrm{c}}{ }^{2}\right) / 3$

$<0.001$

0.508 and $-0.490 \mathrm{e} \AA^{-3}$
Vero cells, suggesting great potential for their in vivo use as antitubercular agents. As for the activity against Vero cells, the highest cytotoxicity was caused by having $-\mathrm{CH}_{3}(\mathbf{1 e})$ and $-\mathrm{OCH}_{3}$ (1g) substituents at the C-7 position of the coumarin, with a percentage survival of 64 and 61\% respectively. A second level of cytotoxicity was observed for the $-\mathrm{CH}_{3}$ (1a) and $-\mathrm{OCH}_{3}$ (1c) substituents at the C- 6 position, with a percentage survival of 76 and $72 \%$ respectively. Whereas, the halogen-substituted
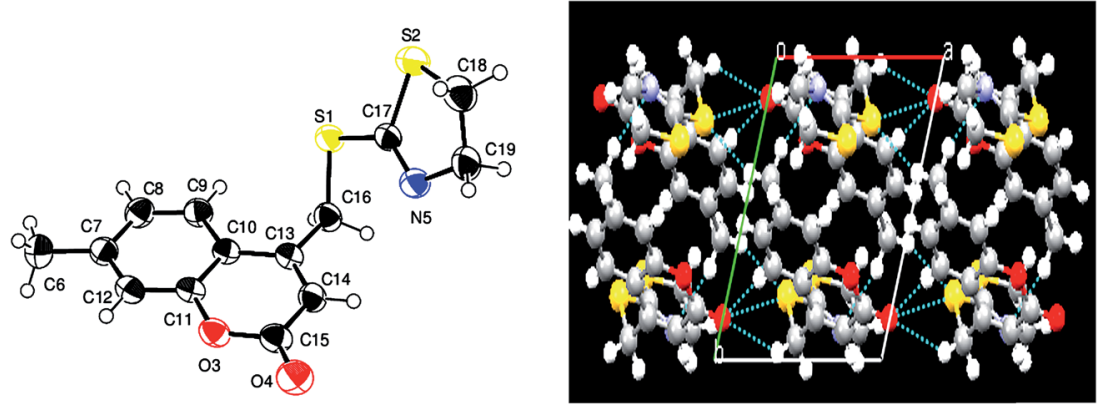

Fig. 7 ORTEP and packing diagrams for compound 1e. Displacement ellipsoids are drawn at the 50\% probability level. Hydrogen atoms are shown as spheres of arbitrary radius. 

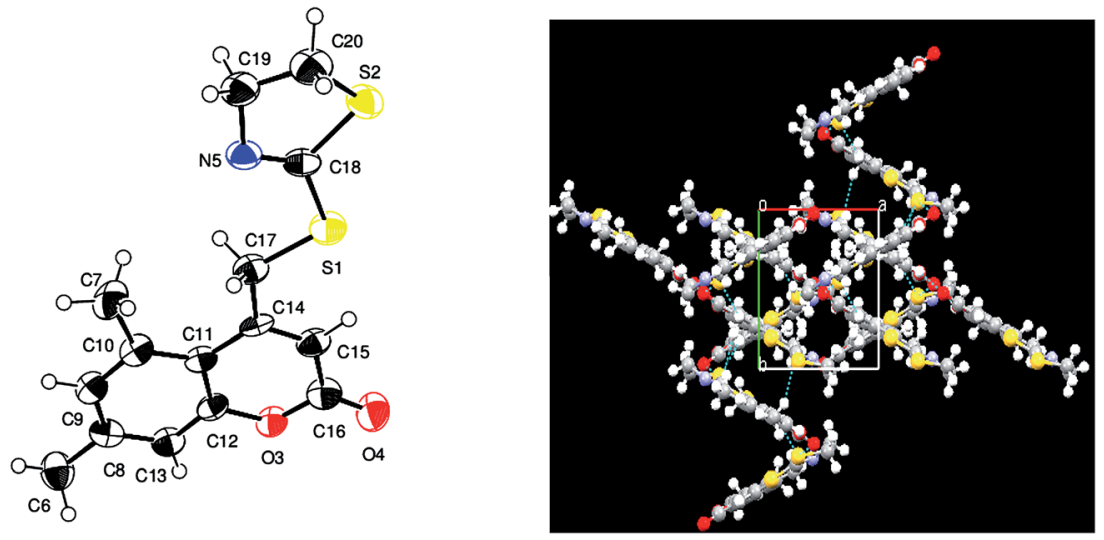

Fig. 8 ORTEP and packing diagrams for compound 1h. Displacement ellipsoids are drawn at the 50\% probability level. Hydrogen atoms are shown as spheres of arbitrary radius.

Table 5 Crystal data, data collection details and structure refinement for $1 \mathrm{~h}$

Empirical formula

Formula weight

Temperature

Wavelength

Crystal system, space group

Unit cell dimensions

Volume

Z

Calculated density

Crystal size

Absorption coefficient

$F(000)$

Crystal form

Radiation source

Radiation type

Radiation monochromator

Criterion for observed reflection

\section{Data collection}

Diffractometer

Data collection method

Absorption correction

Theta range for data collection

Limiting indices

Reflections collected/unique

Completeness to theta

Max. and min. transmission

\section{Refinement}

Refinement method

Data/restraints/parameters

Goodness-of-fit on $F^{2}$

Final $R$ indices $[I>2 \sigma(I)]$

$R$ indices (all data)

Weighting scheme

$(\Delta / \sigma) \max$

Largest diff. peak and hole
$\mathrm{C}_{15} \mathrm{H}_{15} \mathrm{NO}_{2} \mathrm{~S}_{2}$

305.40

$296 \mathrm{~K}$

$0.71073 \AA$

Monoclinic, $P 2_{1} / c$

$a=7.2356(8) \AA$

$b=7.9426(10) \AA$

$c=25.027(3) \AA$

$\alpha=90^{\circ}, \beta=96.742(8)^{\circ}, \gamma=90^{\circ}$

1428.4(3) $\AA^{3}$

4

$1.420 \mathrm{mg} \mathrm{m}^{-3}$

$0.24 \times 0.20 \times 0.12 \mathrm{~mm}$

$0.373 \mathrm{~mm}^{-1}$

640

Plate, yellow

Fine-focus sealed tube

Mo K $\alpha$

Graphite

$I>2 \sigma(I)$

Bruker SMART CCD area-detector

$\omega-\chi$ scans

Multi-scan

1.64 to $22.29^{\circ}$

$-7 \leq h \leq 7,-8 \leq k \leq 8,-26 \leq l \leq 26$

$6121 / 1743[R($ int $)=0.0536]$

$95.2 \%$

$T_{\max }=1.000, T_{\min }=0.770$

Full-matrix least-squares on $F^{2}$

1743/0/181

1.071

$R_{1}=0.0710, \mathrm{w} R_{2}=0.1526$

$R_{1}=0.0954, \mathrm{w} R_{2}=0.1644$

$\omega=1 /\left[\sigma^{2}\left(F_{\mathrm{o}}{ }^{2}\right)+(0.039 P)^{2}+4.4284 P\right]$ where $P=\left(F_{\mathrm{o}}{ }^{2}+2{F_{\mathrm{c}}}^{2}\right) / 3$

$<0.001$

0.309 and $-0.357 \mathrm{e} \AA^{-3}$ 
Table 6 In vitro anti-tubercular screening data of the compounds (1a-1j) against $\mathrm{MtbH}_{37} R v$

\begin{tabular}{|c|c|c|c|c|c|}
\hline Compound & $\mathrm{R}$ & $\begin{array}{l}\% \text { inhibition at } \\
\text { a concentration of } 6.25 \mu \mathrm{g} \mathrm{ml}^{-1}\end{array}$ & $\operatorname{MIC}^{a}\left(\mu \mathrm{g} \mathrm{ml} l^{-1}\right)$ & $\begin{array}{l}\% \text { survival of Vero cells at a concentration } \\
\text { of } 10 \times \mathrm{MIC}^{b}\end{array}$ & $\log P^{c}$ \\
\hline $1 \mathbf{a}$ & 6- $\mathrm{CH}_{3}$ & 93 & 1.56 & $76 \%$ & 3.16 \\
\hline $1 \mathrm{c}$ & 6- $\mathrm{OCH}_{3}$ & 92 & 3.12 & $72 \%$ & 2.76 \\
\hline 1d & 5,6-Benzo & 16 & N.D & N.D & 3.89 \\
\hline $1 \mathrm{e}$ & 7- $\mathrm{CH}_{3}$ & 91 & 6.25 & $64 \%$ & 3.16 \\
\hline $1 \mathrm{~h}$ & $5,7-\mathrm{diCH}_{3}$ & 23 & N.D & N.D & 3.53 \\
\hline $1 \mathbf{i}$ & $6-B r$ & 96 & 0.19 & $91 \%$ & 3.52 \\
\hline $1 j$ & $7-B r$ & 94 & 0.78 & $81 \%$ & 3.52 \\
\hline Isoniazid & - & 100 & 0.02 & $98 \%$ & -0.97 \\
\hline
\end{tabular}

${ }^{a}$ Minimum inhibitory concentration against the $H_{37} R v$ strain of $M t b\left(\mu \mathrm{g} \mathrm{ml}{ }^{-1}\right) .{ }^{b}$ A compound is considered toxic if it causes over $50 \%$ inhibition of normal cells at a concentration 10 fold higher than its MIC. ${ }^{c}$ Calculated using http://www.molinspiration.com/; N.D - not determined.

compounds (1b, 1f, $\mathbf{1 i}$ and $\mathbf{1 j}$ ) exhibited the highest safety profiles with a percentage survival of the Vero cells in the range of $81-94 \%$, which suggest that these compounds can act as new leads for the development of new anti-tubercular drugs. Fig. 9 gives a comparison of the \% survival of the Vero cells at a concentration of the compound which is 10 fold higher than its actual MIC value $\left(\mu \mathrm{g} \mathrm{ml}{ }^{-1}\right)$.

\section{Preliminary SAR study}

Even though the number of compounds tested here is limited, a few key features regarding the structural requirements for the coumarin-thiazoline hybrids $(\mathbf{1 a}-\mathbf{1 j})$ to exert their antitubercular activity may be determined. As we have discussed in the Introduction section, our initial strategy was to identify the key sub-units required for activity such as the coumarin, thiazoline and thioether linker. Additionally, the substituents, like $\mathrm{R}=-\mathrm{CH}_{3}$ (electron donating), $-\mathrm{OCH}_{3}$ (electron releasing), $-\mathrm{Br}$ and $-\mathrm{Cl}$ (halogen), were varied at the C-6 and C-7 positions of the coumarin, since modification of these positions is more favorable for activity and the best output results were obtained with substituents at these particular sites. ${ }^{5 c, 37} \mathrm{~A}$ fused benzo substituent at the 5,6 position of the coumarin (1d) was also involved in the series, since benzo groups fused to coumarins

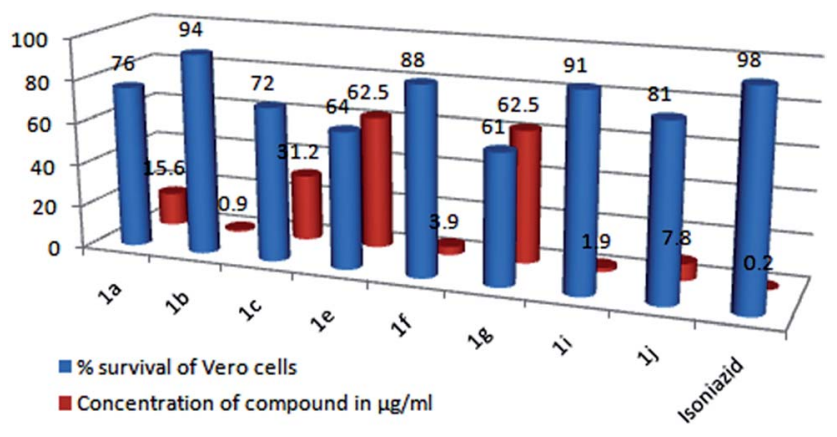

Fig. 9 Comparison of the percentage survival of the Vero cells at a concentration of the compound which is 10 times its actual MIC value $\left(\mu \mathrm{gl}^{-1}\right.$ ). have been reported in photocleavage studies, ${ }^{38}$ and their electronic along with their photo-physical characteristics have resulted in promising biological applications. ${ }^{39}$ Hence based on the structural data the following assumptions about the structure-activity relationship (SAR) were outlined.

From the results, it is clear that the group of compounds having halogen $(-C l \&-B r)$ substituents $(\mathbf{1 b}, \mathbf{1 f}, \mathbf{1 i}$ and $\mathbf{1 j})$ have shown more significant anti-tubercular activity with MICs in the range $0.09-0.78 \mu \mathrm{g} \mathrm{ml} \mathrm{m}^{-1}$. Among them the halogen $(-\mathrm{Cl} \&-\mathrm{Br})$ substituents at the C- 6 position of the coumarin moiety ( $\mathbf{1} \mathbf{b}$ and 1i) greatly enhanced the activity of the compound, obtaining MIC values of 0.09 and $0.19 \mu \mathrm{g} \mathrm{ml}^{-1}$ respectively; in particular, the $-\mathrm{Cl}$ substituent at the C-6 position was found to be the most active in vitro with a MIC of $0.09 \mu \mathrm{g} \mathrm{ml}^{-1}$. A slight change in the position of the halogen from the C-6 to C-7 position decreases the overall activity of the compound, obtaining MIC values of 0.39 and $0.78 \mu \mathrm{g} \mathrm{ml}^{-1}$ for $\mathbf{1 f}$ and $\mathbf{1 j}$ respectively. A second line of activity was shown by the $-\mathrm{CH}_{3}$ (1a) and $-\mathrm{OCH}_{3}$ (1) ) substituents at the C- 6 position of the coumarin obtaining MIC values of 1.56 and $3.12 \mu \mathrm{g} \mathrm{ml}^{-1}$ respectively, whereas those compounds with $-\mathrm{CH}_{3}(\mathbf{1 e})$ and $-\mathrm{OCH}_{3}(\mathbf{1 g})$ at the $\mathrm{C}-7$ position of the coumarin exhibited moderate activity with a similar MIC value of $6.25 \mu \mathrm{g}$ $\mathrm{ml}^{-1}$. Here the substituents at the C-6 position have shown much better results than those at the C-7 position of the coumarin moiety; while the 5,6-benzo (1d) and 5,7-diCH 3 (1h) substituents were found to be inactive against the $M t b H_{37} R v$ strain. From the above results it is evident that the halogen substituents dominated the overall activity. The reason for this increase in activity may be attributed to the high lipophilic nature of the halogen and it being less water soluble, hence penetration of the drug or drug lead into a cell wall of lipid membrane is much more easy and thereby the bioavailability of the compound is increased. ${ }^{40}$ However, the other substituents $\left(-\mathrm{CH}_{3},-\mathrm{OCH}_{3}, 5,6\right.$-benzo \& 5,7- $\left.\mathrm{CH}_{3}\right)$ have shown mixed activity and no proper SAR could be explained for these substituents. Although it is worth mentioning that the $-\mathrm{CH}_{3},-\mathrm{OCH}_{3}$ and halogen substituents $(-\mathrm{Cl} \&-\mathrm{Br})$ at the $\mathrm{C}-6$ position were found to be more active than the same substituents at the $\mathrm{C}-7$ position of the coumarin ring. The results from the preliminary 
structure-activity analysis have led to the determination of some key structural requirements for the coumarin-thiazoline hybrids to exert their anti-TB activity, which provides insight for further structural modifications.

\section{Electrophoresis analysis}

The design and development of small- or medium-sized potential therapeutic agents to target nucleic acid cleavage can lead to the synthesis of novel therapeutic agents for infectious diseases and can act as a tool for molecular biology. Interaction of small molecules with specific sites along a DNA strand as a reactive model for protein-nucleic acid bindings provides a path toward rational drug design as well as a means to develop sensitive chemical probes for DNA. The different loci present in DNA are involved in various regulatory processes such as gene expression, gene transcription, mutagenesis, carcinogenesis, etc. ${ }^{41}$ In particular, designing of the compound based on its ability to cleave DNA is of great importance not only from the primary biological point of view but also in terms of a photodynamic therapeutic approach to develop potent drugs. ${ }^{42}$ Hence to understand the mode of action of the synthesized compounds (1a-1j) and to identify new molecules that induce apoptosis, i.e. programmed cell death, we carried out a CT-DNA cleavage assay using an agarose gel electrophoresis method, and the results are presented in Fig. 10. The cleavage potential of the test compounds was assessed by comparing the bands that appeared for the control and test compounds at $5 \mu \mathrm{M}$ concentration. The DNA alone without the test compound was used as a control, which did not show any cleavage of DNA even after a long exposure time. From the photograph (Fig. 10) it is clear that compounds $\mathbf{1 b}, \mathbf{1 d}, \mathbf{1 f}$ and $\mathbf{1 i}$ cleaved the DNA more efficiently, as no traces of DNA were found suggesting that the cleavage of DNA by the compounds may be attributed to the denaturation of double-stranded DNA by cleavage of the hydrogen bonds between the nitrogen bases and the phosphodiester bonds between the pentose sugars at various sites. In addition, cleavage of the DNA might have occurred frequently leading to low molecular weight fragments and these small fragments have migrated away from the gel during electrophoresis. The remaining compounds $\mathbf{1 a}, \mathbf{1 c}, \mathbf{1 g}, \mathbf{1 h}$ and $\mathbf{1 j}$ were found to be inactive for cleavage of DNA, whereas a little tailing of the band can be observed in the sample treated with compound 1e indicating shearing of the DNA. From a structural point of view it is observed that the halogen substituents at the 6 and 7 position of the coumarin moiety $(\mathbf{1 b}, \mathbf{1 f}, \mathbf{1 i}$ and $\mathbf{1 j})$ exhibited nearly similar MIC values with distinct antitubercular activity in the range $0.09-0.78 \mu \mathrm{g} \mathrm{ml}^{-1}$, whereas in the DNA cleavage assay, except for the $-B r$ substituent at the 7 position (1j), all the remaining halogen substituent compounds (1b, $\mathbf{1 f}$ and 1i) cleave the DNA more efficiently. This indicates that the nuclease activity may be dependent on the position of the $-\mathrm{Br}$ group. Also, if we compare the MIC values of all the halogensubstituted compounds, the compound with a $-B r$ substituent at the 7 position (1j) exhibited the least activity with a MIC of $0.78 \mu \mathrm{g} \mathrm{ml} \mathrm{m}^{-1}$. Hence, this slight decrease in activity of compound $\mathbf{1 j}$ may be attributed to not cleaving the genomic
DNA of the $\mathrm{MtbH}_{37}$ strain or that the target site of compound $\mathbf{1 j}$ may be any other cell organelles of the $\mathrm{MtbH}_{37}$ strain but not DNA. It is also noted that compound 1d, which was inactive against the $\mathrm{MtbH}_{37}$ strain, cleaved DNA more efficiently. This indicated that the nuclease activity is dependent on the substituent attached to the coumarin moiety. Furthermore, the concentration of compound $\mathbf{1 d}$ used for the in vitro assay may be insufficient to reach the target site, since in the DNA cleavage assay the genomic DNA is directly subjected to the tested compound whereas the MIC study is related to the resistance of the strain $\left(\mathrm{MtbH}_{37}\right)$ to the tested compound due to many factors. However, the nature of the reactive intermediates involved in the DNA cleavage by the compounds has not been clear.

\section{Materials and methods}

\section{Instrumentation}

Melting points were determined using an open capillary method on a Buchi apparatus and are uncorrected. IR spectra were recorded on a Nicolet 5700 FT-IR instrument (Nicolet, Madison, WI, USA) using $\mathrm{KBr}$ discs. ${ }^{1} \mathrm{H}$ NMR spectra were recorded on a Bruker $400 \mathrm{MHz}$ spectrometer using $\mathrm{CDCl}_{3}$ as the solvent and TMS as an internal standard. All chemical shifts are reported as $\delta$ values (ppm). Mass spectra were recorded using a Shimadzu GCMSQP2010S. The elemental analyses were carried out using a Hereaus CHN rapid analyzer. The microwave irradiation syntheses were carried out using a CEM-Discover Focused Microwave system. The purity of the compounds was checked using TLC. The X-ray single-crystal structures of compounds 1a, $\mathbf{1 b}, \mathbf{1 e}$ and $\mathbf{1 h}$ were recorded using a Bruker Smart CCD and refined using the SHELXL Software Package.

\section{General procedure for the preparation of compounds $1 \mathrm{a}-\mathbf{1 j}$}

Conventional method. A mixture of 4,5-dihydrothiazole-2thiol $(0.01 \mathrm{~mol})$ and powdered anhydrous $\mathrm{K}_{2} \mathrm{CO}_{3}(0.03 \mathrm{~mol})$ with the substituted 4-bromomethyl coumarin $(0.01 \mathrm{~mol})$ in 5 $\mathrm{ml}$ absolute ethanol was stirred at room temperature for 10-14 $\mathrm{h}$. The progress of the reaction was examined using thin layer chromatography (TLC). After completion of the reaction, the reaction mixture was quenched in crushed ice; the solid product was filtered and washed with water. Lastly, the product was recrystallized from chloroform.

Microwave method. A mixture of 4,5-dihydrothiazole-2-thiol $(0.01 \mathrm{~mol})$ and powdered anhydrous $\mathrm{K}_{2} \mathrm{CO}_{3}(0.03 \mathrm{~mol})$ with the

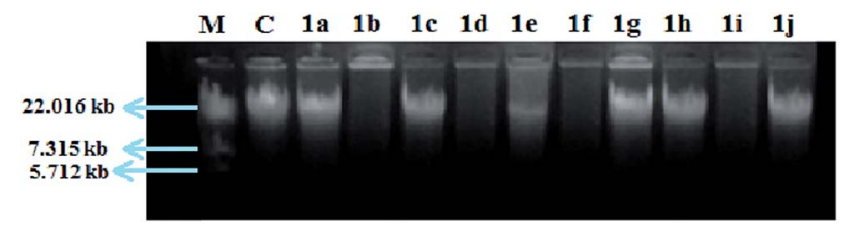

Fig. 10 CT-DNA cleavage study using agarose gel electrophoresis. Lane M: standard DNA marker, Lane C: control DNA (untreated sample), Lane 1a: DNA + 1a, Lane 1b: DNA + 1b, Lane 1c: DNA + 1c, Lane 1d: DNA + 1d, Lane 1e: DNA + 1e, Lane 1f: DNA + 1f, Lane 1g: DNA + 1g, Lane 1h: DNA + 1h, Lane 1i: DNA + 1i, Lane 1j: DNA + 1j. 
substituted 4-bromomethyl coumarin $(0.01 \mathrm{~mol})$ was put into a $10 \mathrm{ml}$ microwave pressure vial and irradiated in a microwave oven (model: CEM-Discover Focused Microwave system) under $100 \mathrm{~W}$ power at $55^{\circ} \mathrm{C}$ for $5-9 \mathrm{~min}$ in $5 \mathrm{ml}$ absolute ethanol. The progress of the reaction was examined using thin layer chromatography (TLC). After completion of the reaction, the reaction mixture was quenched in crushed ice; the solid product was filtered and washed with water. Lastly the product was recrystallized from chloroform.

\section{Characterization of the compounds}

4-[(4,5-Dihydro-1,3-thiazol-2-ylthio)methyl]-6-methyl-2Hchromen-2-one (1a). Colourless crystals; mp 165-167 ${ }^{\circ} \mathrm{C}$; IR $(\mathrm{KBr})\left(v_{\max } / \mathrm{cm}^{-1}\right): 1713(\mathrm{C}=\mathrm{O}$ of lactone $), 1574(\mathrm{C}=\mathrm{N}$ of thiazole) $\mathrm{cm}^{-1} ;{ }^{1} \mathrm{H}$ NMR (400 MHz, $\left.\mathrm{CDCl}_{3}, \delta \mathrm{ppm}\right) \delta 2.42(\mathrm{~s}, 3 \mathrm{H}$, $\left.\mathrm{CH}_{3}\right), 3.45\left(\mathrm{t}, 2 \mathrm{H}, \mathrm{CH}_{2}, J=8 \mathrm{~Hz}\right), 4.23\left(\mathrm{t}, 2 \mathrm{H}, \mathrm{CH}_{2}, J=8 \mathrm{~Hz}\right), 4.45$ $\left(\mathrm{s}, 2 \mathrm{H}, \mathrm{CH}_{2}\right), 6.56(\mathrm{~s}, 1 \mathrm{H}, \mathrm{CH}), 7.24(\mathrm{~d}, 1 \mathrm{H}, \mathrm{Ar}-\mathrm{H}, J=8.4 \mathrm{~Hz}), 7.34$ (dd, $1 \mathrm{H}, \mathrm{Ar}-\mathrm{H}, J=8.6 \mathrm{~Hz}, 2 \mathrm{~Hz}), 7.40$ (s, 1H, Ar-H); ${ }^{13} \mathrm{C}$ NMR $(100$ $\left.\mathrm{MHz}, \mathrm{CDCl}_{3}, \delta \mathrm{ppm}\right): 21.03,32.06,36.10,63.89,115.95,117.10$, 117.91, 124.01, 132.96, 134.00, 149.99, 151.96, 160.73, 163.59; GC-MS: $291[\mathrm{M}]^{+}$; anal. calcd for $\mathrm{C}_{14} \mathrm{H}_{13} \mathrm{NO}_{2} \mathrm{~S}_{2}$ : C, 57.71; H, 4.50; $\mathrm{N}, 4.81 \%$. Found: C, $57.68 ; \mathrm{H}, 4.54 ; \mathrm{N}, 4.85 \%$.

6-Chloro-4-[(4,5-dihydro-1,3-thiazol-2-ylthio)methyl]-2Hchromen-2-one (1b). Yellow crystals; mp 181-183 ${ }^{\circ} \mathrm{C}$; IR $(\mathrm{KBr})$ $\left(v_{\max } / \mathrm{cm}^{-1}\right): 1716(\mathrm{C}=\mathrm{O}$ of lactone), $1577(\mathrm{C}=\mathrm{N}$ of thiazole $)$ $\mathrm{cm}^{-1} ;{ }^{1} \mathrm{H}$ NMR (400 MHz, $\left.\mathrm{CDCl}_{3}, \delta \mathrm{ppm}\right) \delta 3.55\left(\mathrm{t}, 2 \mathrm{H}, \mathrm{CH}_{2}, J=8\right.$ $\mathrm{Hz}), 4.33\left(\mathrm{t}, 2 \mathrm{H}, \mathrm{CH}_{2}, J=8 \mathrm{~Hz}\right), 4.55\left(\mathrm{~s}, 2 \mathrm{H}, \mathrm{CH}_{2}\right), 6.96(\mathrm{~s}, 1 \mathrm{H}$, $\mathrm{CH}), 7.31$ (d, $1 \mathrm{H}, \mathrm{Ar}-\mathrm{H}, J=8.4 \mathrm{~Hz}), 7.54(\mathrm{~d}, 1 \mathrm{H}, \mathrm{Ar}-\mathrm{H}, J=8.4 \mathrm{~Hz})$, 7.66 (s, $1 \mathrm{H}, \mathrm{Ar}-\mathrm{H}) ;{ }^{13} \mathrm{C} \mathrm{NMR}\left(100 \mathrm{MHz}, \mathrm{CDCl}_{3}, \delta \mathrm{ppm}\right): 31.95$, 36.05 , 64.11, 116.13, 117.43, 118.21, 123.96, 133.06, 133.92, 150.08, 152.53, 160.11, 162.94; GC-MS: 311[M] $]^{+}, 313[\mathrm{M}+2]^{+}$; anal. calcd for $\mathrm{C}_{13} \mathrm{H}_{10} \mathrm{ClNO}_{2} \mathrm{~S}_{2}$ : C, 50.08; H, 3.23; N, $4.49 \%$. Found: C, 50.05; H, 3.28; N, 4.54\%.

4-((4,5-Dihydrothiazol-2-ylthio)methyl)-6-methoxy-2H-

chromen-2-one (1c). Colourless crystals; mp 163-165 ${ }^{\circ} \mathrm{C}$; IR $(\mathrm{KBr})\left(v_{\max } / \mathrm{cm}^{-1}\right): 1713(\mathrm{C}=\mathrm{O}$ of lactone $), 1584(\mathrm{C}=\mathrm{N}$ of thiazole) $\mathrm{cm}^{-1} ;{ }^{1} \mathrm{H}$ NMR (400 MHz, $\left.\mathrm{CDCl}_{3}, \delta \mathrm{ppm}\right) \delta 3.37\left(\mathrm{t}, 2 \mathrm{H}, \mathrm{CH}_{2}\right.$, $J=8 \mathrm{~Hz}), 3.73\left(\mathrm{~s}, 3 \mathrm{H},-\mathrm{OCH}_{3}\right), 4.15\left(\mathrm{t}, 2 \mathrm{H}, \mathrm{CH}_{2}, J=8 \mathrm{~Hz}\right), 4.52(\mathrm{~s}$, $2 \mathrm{H}, \mathrm{CH}_{2}$ ), 6.48 (s, 1H, CH), 7.14 (d, 1H, Ar-H, $\left.J=8.4 \mathrm{~Hz}\right), 7.28$ (dd, $1 \mathrm{H}, \mathrm{Ar}-\mathrm{H}, J=8.4 \mathrm{~Hz}, 1.6 \mathrm{~Hz}), 7.41$ (s, 1H, Ar-H); ${ }^{13} \mathrm{C}$ NMR (100 MHz, $\left.\mathrm{CDCl}_{3}, \delta \mathrm{ppm}\right): 32.40,37.70,55.44,62.15,115.40$, 117.51, 118.97, 124.00, 132.01, 133.75, 149.91, 152.06, 159.73, 162.97; GC-MS: $307[\mathrm{M}]^{+}$; anal. calcd for $\mathrm{C}_{14} \mathrm{H}_{13} \mathrm{NO}_{3} \mathrm{~S}_{2}$ : C, 54.70; H, 4.26; N, 4.56\%. Found: C, 54.75; H, 4.30; N, 4.60\%.

1-((4,5-Dihydrothiazol-2-ylthio)methyl)-3H-benzo[f] chromen-3-one (1d). Brown solid; mp 190-192 ${ }^{\circ} \mathrm{C}$; IR (KBr) $\left(v_{\max } / \mathrm{cm}^{-1}\right): 1707(\mathrm{C}=\mathrm{O}$ of lactone), $1601(\mathrm{C}=\mathrm{N}$ of thiazole) $\mathrm{cm}^{-1} ;{ }^{1} \mathrm{H}$ NMR (400 MHz, $\left.\mathrm{CDCl}_{3}, \delta \mathrm{ppm}\right) \delta 3.43\left(\mathrm{t}, 2 \mathrm{H}, \mathrm{CH}_{2}, J=8\right.$ $\mathrm{Hz}), 4.22\left(\mathrm{t}, 2 \mathrm{H}, \mathrm{CH}_{2}, J=8 \mathrm{~Hz}\right), 4.49\left(\mathrm{~s}, 2 \mathrm{H}, \mathrm{CH}_{2}\right), 6.61(\mathrm{~s}, 1 \mathrm{H}$, $\mathrm{CH}), 7.53-7.66(\mathrm{~m}, 4 \mathrm{H}), 7.82(\mathrm{dd}, 1 \mathrm{H}, J=8.4 \mathrm{~Hz}, 1.6 \mathrm{~Hz}), 8.48$ (d, $1 \mathrm{H}, J=8.8 \mathrm{~Hz}) ;{ }^{13} \mathrm{C} \mathrm{NMR}\left(100 \mathrm{MHz}, \mathrm{CDCl}_{3}, \delta \mathrm{ppm}\right): 32.58,36.10$, $63.91,113.55,115.20,119.76,122.56,123.21,124.30,127.22$, 127.63, 128.80, 134.75, 151.01, 151.07, 160.60, 163.53; GC-MS: $327[\mathrm{M}]^{+}$; anal. calcd for $\mathrm{C}_{17} \mathrm{H}_{13} \mathrm{NO}_{2} \mathrm{~S}_{2}: \mathrm{C}, 62.36 ; \mathrm{H}, 4.00 ; \mathrm{N}$, $4.28 \%$. Found: C, 62.39; H, 4.04; N, 4.25\%.
4-((4,5-Dihydrothiazol-2-ylthio)methyl)-7-methyl-2Hchromen-2-one (1e). Colourless crystals; mp 167-169 ${ }^{\circ} \mathrm{C}$; IR $(\mathrm{KBr})\left(v_{\max } / \mathrm{cm}^{-1}\right): 1713(\mathrm{C}=\mathrm{O}$ of lactone $), 1597(\mathrm{C}=\mathrm{N}$ of thiazole) $\mathrm{cm}^{-1}$; ${ }^{1} \mathrm{H}$ NMR (400 $\left.\mathrm{MHz}, \mathrm{CDCl}_{3}, \delta \mathrm{ppm}\right) \delta 2.38(\mathrm{~s}, 3 \mathrm{H}$, $\left.\mathrm{CH}_{3}\right), 3.41\left(\mathrm{t}, 2 \mathrm{H}, \mathrm{CH}_{2}, J=8 \mathrm{~Hz}\right), 4.19\left(\mathrm{t}, 2 \mathrm{H}, \mathrm{CH}_{2}, J=8 \mathrm{~Hz}\right), 4.41$ $\left(\mathrm{s}, 2 \mathrm{H}, \mathrm{CH}_{2}\right), 6.51(\mathrm{~s}, 1 \mathrm{H},-\mathrm{CH}), 7.18(\mathrm{~d}, 1 \mathrm{H}, J=8.4 \mathrm{~Hz}), 7.30$ (dd, $1 \mathrm{H}, J=8.4 \mathrm{~Hz}, 1.6 \mathrm{~Hz}), 7.37(\mathrm{~s}, 1 \mathrm{H}) ;{ }^{13} \mathrm{C} \mathrm{NMR}\left(100 \mathrm{MHz}, \mathrm{CDCl}_{3}, \delta\right.$ ppm): 21.01, 32.05, 36.11, 63.88, 115.90, 117.05, 117.90, 124.02, 132.95, 134.01, 150.02, 151.92, 160.67, 163.55; GC-MS: 291[M] ${ }^{+}$; anal. calcd for $\mathrm{C}_{14} \mathrm{H}_{13} \mathrm{NO}_{2} \mathrm{~S}_{2}$ : C, $57.71 ; \mathrm{H}, 4.50 ; \mathrm{N}, 4.81 \%$. Found: C, 57.75; H, 4.54; N, 4.83\%.

7-Chloro-4-((4,5-dihydrothiazol-2-ylthio)methyl)-2H-

chromen-2-one (1f). Yellow crystals; mp 183-185 ${ }^{\circ} \mathrm{C}$; IR (KBr) $\left(v_{\max } / \mathrm{cm}^{-1}\right): 1711(\mathrm{C}=\mathrm{O}$ of lactone), $1579(\mathrm{C}=\mathrm{N}$ of thiazole $)$ $\mathrm{cm}^{-1} ;{ }^{1} \mathrm{H}$ NMR (400 MHz, $\left.\mathrm{CDCl}_{3}, \delta \mathrm{ppm}\right) \delta 3.45\left(\mathrm{t}, 2 \mathrm{H}, \mathrm{CH}_{2}, J=8\right.$ $\mathrm{Hz}), 4.22\left(\mathrm{t}, 2 \mathrm{H}, \mathrm{CH}_{2}, J=8 \mathrm{~Hz}\right), 4.41\left(\mathrm{~s}, 2 \mathrm{H}, \mathrm{CH}_{2}\right), 6.58(\mathrm{~s}, 1 \mathrm{H})$, $7.27(\mathrm{~d}, 1 \mathrm{H}, J=8.8 \mathrm{~Hz}), 7.46(\mathrm{dd}, 1 \mathrm{H}, J=8.6 \mathrm{~Hz}, 2 \mathrm{~Hz}), 7.64(\mathrm{~s}$, $1 \mathrm{H}) ;{ }^{13} \mathrm{C}$ NMR (100 MHz, $\left.\mathrm{CDCl}_{3}, \delta \mathrm{ppm}\right): 31.89,36.23,63.76$, $117.01,118.73,119.36,124.05,129.79,132.01,149.34,152.25$, 159.80, 163.44; GC-MS: $311[\mathrm{M}]^{+}, 313[\mathrm{M}+2]^{+}$; anal. calcd for $\mathrm{C}_{13} \mathrm{H}_{10} \mathrm{ClNO}_{2} \mathrm{~S}_{2}$ : C, 50.08; H, 3.23; N, 4.49\%. Found: C, 50.05; H, 3.27 ; N, $4.45 \%$.

4-((4,5-Dihydrothiazol-2-ylthio)methyl)-7-methoxy-2Hchromen-2-one (1g). Colourless crystals; mp 165-167 ${ }^{\circ} \mathrm{C}$; IR $(\mathrm{KBr})\left(v_{\max } / \mathrm{cm}^{-1}\right): 1716(\mathrm{C}=\mathrm{O}$ of lactone $), 1589(\mathrm{C}=\mathrm{N}$ of thiazole) $\mathrm{cm}^{-1} ;{ }^{1} \mathrm{H}$ NMR (400 MHz, $\left.\mathrm{CDCl}_{3}, \delta \mathrm{ppm}\right) \delta 3.40(\mathrm{t}, 2 \mathrm{H}$, $\left.-\mathrm{CH}_{2}, J=8 \mathrm{~Hz}\right), 3.83\left(\mathrm{~s}, 3 \mathrm{H},-\mathrm{OCH}_{3}\right), 4.21\left(\mathrm{t}, 2 \mathrm{H}, \mathrm{CH}_{2}, J=8 \mathrm{~Hz}\right)$, $4.41\left(\mathrm{~s}, 2 \mathrm{H}, \mathrm{CH}_{2}\right), 6.59(\mathrm{~s}, 1 \mathrm{H}), 7.20(\mathrm{~d}, 1 \mathrm{H}, \mathrm{Ar}-\mathrm{H}, J=8 \mathrm{~Hz}), 7.31$ $(\mathrm{s}, 1 \mathrm{H}, J=8.4 \mathrm{~Hz}), 7.40(\mathrm{~s}, 1 \mathrm{H}) ;{ }^{13} \mathrm{C} \mathrm{NMR}\left(100 \mathrm{MHz} \mathrm{CDCl}_{3}, \delta\right.$ ppm): 32.75, 36.66, 56.75, 63.08, 116.18, 117.14, 118.81, 123.75, 134.01, 134.68, 148.74, 152.31, 161.03, 163.42; GC-MS: 307[M] $]^{+}$; anal. calcd for $\mathrm{C}_{14} \mathrm{H}_{13} \mathrm{NO}_{3} \mathrm{~S}_{2}$ : C, 54.70; H, 4.26; N, 4.56\%. Found: C, 54.75; H, 4.24; N, 4.60\%.

4-((4,5-Dihydrothiazol-2-ylthio)methyl)-5,7-dimethyl-2Hchromen-2-one (1h). Yellow crystals; mp 182-184 ${ }^{\circ} \mathrm{C}$; IR ( $\left.\mathrm{KBr}\right)$ $\left(v_{\max } / \mathrm{cm}^{-1}\right): 1709(\mathrm{C}=\mathrm{O}$ of lactone), $1597(\mathrm{C}=\mathrm{N}$ of thiazole $)$ $\mathrm{cm}^{-1} ;{ }^{1} \mathrm{H}$ NMR $\left(400 \mathrm{MHz}, \mathrm{CDCl}_{3}, \delta \mathrm{ppm}\right) \delta 2.29\left(\mathrm{~s}, 3 \mathrm{H}, \mathrm{CH}_{3}\right)$, $2.64\left(\mathrm{~s}, 3 \mathrm{H}, \mathrm{CH}_{3}\right), 3.41\left(\mathrm{t}, 2 \mathrm{H}, \mathrm{CH}_{2}, J=8 \mathrm{~Hz}\right), 4.16\left(\mathrm{t}, 2 \mathrm{H}, \mathrm{CH}_{2}, J=\right.$ $8 \mathrm{~Hz}), 4.42\left(\mathrm{~s}, 2 \mathrm{H}, \mathrm{CH}_{2}\right), 6.46(\mathrm{~s}, 1 \mathrm{H}), 6.82(\mathrm{~s}, 1 \mathrm{H}), 6.98(\mathrm{~s}, 1 \mathrm{H})$; ${ }^{13} \mathrm{C}$ NMR (100 MHz, $\left.\mathrm{CDCl}_{3}, \delta \mathrm{ppm}\right): 21.14,23.95,35.99,36.15$, $63.86,115.25$, 116.51, 116.57, 130.17, 135.57, 142.19, 151.29, 155.73, 160.42, 163.78; GC-MS: $305[\mathrm{M}]^{+}$; anal. calcd for $\mathrm{C}_{15} \mathrm{H}_{15} \mathrm{NO}_{2} \mathrm{~S}_{2}$ : C, 58.99; H, 4.95; N, 4.59\%. Found: C, 58.75; H, $4.89 ; \mathrm{N}, 4.63 \%$.

6-Bromo-4-((4,5-dihydrothiazol-2-ylthio)methyl)-2Hchromen-2-one (1i). Yellow crystals; mp 175-177 ${ }^{\circ} \mathrm{C}$; IR (KBr) $\left(v_{\max } / \mathrm{cm}^{-1}\right): 1715(\mathrm{C}=\mathrm{O}$ of lactone), $1601(\mathrm{C}=\mathrm{N}$ of thiazole $)$ $\mathrm{cm}^{-1} ;{ }^{1} \mathrm{H}$ NMR (400 MHz, $\left.\mathrm{CDCl}_{3}, \delta \mathrm{ppm}\right) \delta 3.51\left(\mathrm{t}, 2 \mathrm{H}, \mathrm{CH}_{2}, J=8\right.$ $\mathrm{Hz}), 4.14\left(\mathrm{t}, 2 \mathrm{H}, \mathrm{CH}_{2}, J=8 \mathrm{~Hz}\right), 4.56\left(\mathrm{~s}, 2 \mathrm{H}, \mathrm{CH}_{2}\right), 6.61(\mathrm{~s}, 1 \mathrm{H})$, $7.34(\mathrm{~d}, 1 \mathrm{H}, J=8 \mathrm{~Hz}), 7.41(\mathrm{~d}, 1 \mathrm{H}, J=7.6 \mathrm{~Hz}), 7.60(\mathrm{~s}, 1 \mathrm{H}) ;{ }^{13} \mathrm{C}$ NMR (100 MHz, $\left.\mathrm{CDCl}_{3}, \delta \mathrm{ppm}\right): 32.11,36.01,64.13,117.12$, 117.46, 120.16, 127.15, 133.63, 137.26, 149.81, 153.75, 161.13, 163.78; GC-MS: $311[\mathrm{M}]^{+}, 313[\mathrm{M}+2]^{+}$; anal. calcd for $\mathrm{C}_{13} \mathrm{H}_{10^{-}}$ $\mathrm{BrNO}_{2} \mathrm{~S}_{2}$ : C, 43.83; H, 2.83; N, 3.93\%. Found: C, 43.89; H, 2.87; $\mathrm{N}, 3.98 \%$. 
7-Bromo-4-((4,5-dihydrothiazol-2-ylthio)methyl)-2Hchromen-2-one (1j). Yellow crystals; mp 179-181 ${ }^{\circ} \mathrm{C}$; IR (KBr) $\left(v_{\max } / \mathrm{cm}^{-1}\right): 1718(\mathrm{C}=\mathrm{O}$ of lactone), $1583(\mathrm{C}=\mathrm{N}$ of thiazole $)$ $\mathrm{cm}^{-1} ;{ }^{1} \mathrm{H}$ NMR (400 MHz, $\left.\mathrm{CDCl}_{3}, \delta \mathrm{ppm}\right) \delta 3.43\left(\mathrm{t}, 2 \mathrm{H}, \mathrm{CH}_{2}, J=8\right.$ $\mathrm{Hz}), 4.21\left(\mathrm{t}, 2 \mathrm{H}, \mathrm{CH}_{2}, J=8 \mathrm{~Hz}\right), 4.48\left(\mathrm{~s}, 2 \mathrm{H}, \mathrm{CH}_{2}\right), 6.61(\mathrm{~s}, 1 \mathrm{H})$, $7.41(\mathrm{~d}, 1 \mathrm{H}, J=8.4 \mathrm{~Hz}), 7.61(\mathrm{dd}, 1 \mathrm{H}, J=7.6 \mathrm{~Hz}, 1.6 \mathrm{~Hz}), 7.82(\mathrm{~s}$, $1 \mathrm{H}) ;{ }^{13} \mathrm{C}$ NMR (100 MHz, $\left.\mathrm{CDCl}_{3}, \delta \mathrm{ppm}\right): 33.09,36.13,64.22$, 116.22, 117.49, 119.13, 126.82, 131.18, 135.12, 150.09, 153.49, 161.46, 164.03; GC-MS: $311[\mathrm{M}]^{+}, 313[\mathrm{M}+2]^{+}$; anal. calcd for $\mathrm{C}_{13} \mathrm{H}_{10} \mathrm{BrNO}_{2} \mathrm{~S}_{2}: \mathrm{C}, 43.83 ; \mathrm{H}, 2.83 ; \mathrm{N}, 3.93 \%$. Found: C, 43.80; H, 2.89; N, 3.97\%.

\section{Anti-tubercular assay}

All the compounds were first screened at a concentration of 6.25 $\mu \mathrm{g} \mathrm{ml} \mathrm{m}^{-1}$ against $M$. tuberculosis $H_{37} R v$ (ATCC-27294) in BACTEC 12 B medium using the Microplate Alamar Blue Assay (MABA). Compounds exhibiting $<90 \%$ inhibition in the primary screening were not evaluated further, while compounds exhibiting $>90 \%$ inhibition were re-tested against $\mathrm{MtbH}_{37} \mathrm{Rv}$ at lower concentrations in order to determine the actual minimum inhibitory concentration (MIC) in the MABA. The experiments were carried out in triplicate using a 96-well plate; to each well $100 \mu \mathrm{l}$ of Middlebrook $7 \mathrm{H} 9$ broth was added and a serial dilution of the compound was made directly on the plate. Firstly, $200 \mathrm{ml}$ of sterile deionized water was added to all outer perimeter wells of a sterile 96-well plate to minimize evaporation of the medium in the test wells during incubation. Isoniazid was included as a positive drug control. The test compounds were serially diluted using a two-fold serial dilution method. The plates were covered and sealed with para film and incubated at $37{ }^{\circ} \mathrm{C}$ for 5 days. After this, $25 \mathrm{ml}$ of a freshly prepared 1:1 mixture of Alamar Blue reagent and 10\% tween 80 was added to the plate and incubated for $24 \mathrm{~h}$. A blue color in the wells indicated inhibition of bacterial growth while a pink color was recorded as growth. Furthermore, the minimum concentration of the compound required to inhibit the bacterial growth was determined.

\section{Assay for in vitro cytotoxicity against Vero cells}

The cytotoxicity of the compounds with a MIC $\leq 6.25 \mu \mathrm{g} \mathrm{ml}^{-1}$ was evaluated using Vero cells. The Vero cells were cultured in Dulbecco Modified Eagle Medium (DMEM) containing $2 \mathrm{mM}$ $\mathrm{Na}_{2} \mathrm{CO}_{3}$ supplemented with $10 \%$ (v/v) fetal bovine serum (FBS). The cells were incubated at $37{ }^{\circ} \mathrm{C}$ under $5 \% \mathrm{CO}_{2}$ and $95 \%$ air in a humidified atmosphere until confluent and then diluted with phosphate-buffered saline to obtain $10^{6}$ cells per ml. Stock solutions were prepared in dimethyl sulfoxide (DMSO) and further dilutions were made with fresh culture medium. The medium was removed and replaced by $180 \mathrm{ml}$ of fresh medium containing the test compound at a concentration 10 fold its actual MIC value. After incubation at $37^{\circ} \mathrm{C}$ for $72 \mathrm{~h}$, the medium was removed and the monolayer was washed twice with $100 \mu \mathrm{L}$ of warm Hanks' balanced salt solution (HBSS). One hundred microliters of warm medium and $20 \mu \mathrm{L}$ of freshly made MTSPMS [3-(4,5-dimethylthiazol-2-yl)-5-(3-carboxymethoxyphenyl)2-(4-sulfophenyl)-2 $H$-tetrazolium and phenylmethasulfazone]
(100:20) (Promega) were added to each well, the plates were incubated for $3 \mathrm{~h}$, and the absorbance was determined at 560 nm using a microplate reader. The percentage of cell survival was calculated after considering the control wells (cells incubated in DMSO-containing medium).

\section{Sample preparation}

Calf-Thymus DNA (CT-DNA) was procured from Merck Bangalore. A DNA stock solution was prepared by diluting the CT-DNA in TE buffer. The test compounds $(5 \mu \mathrm{M})$ were dissolved in DMSO and added separately to the $10 \mu \mathrm{l}$ of CT-DNA and then incubated at $37^{\circ} \mathrm{C}$ for $2 \mathrm{~h}$.

\section{Agarose gel electrophoresis}

The cleavage of Calf-Thymus DNA (CT-DNA) by the products was analyzed using an agarose gel electrophoresis method. The gel was prepared by adding $200 \mathrm{mg}$ of agarose in $25 \mathrm{ml}$ of TAE buffer (4.84 g Tris base, pH 8.0, $0.5 \mathrm{M}$ EDTA per 1 liter). The mixture was heated to dissolve the agarose completely; thereafter it was slightly cooled and $5 \mu$ l of ethidium bromide was added. Then the molten agarose was poured into a casting tray and a comb was placed in it for the formation of wells and it was allowed to solidify. After solidification the comb was removed and the tray was placed in a tank wherein the tank buffer (TAE) was poured. Then the wells were loaded with $10 \mu \mathrm{l}$ of DNA, $5 \mu \mathrm{m}$ of the test compound and $10 \mu \mathrm{l}$ of the tracking dye $(10 \mathrm{mM}$ tris pH 8.0, 1 mM EDTA, 30\% glycerol, 0.2\% bromophenol blue). Electrophoresis was performed at 50 volts for $45 \mathrm{~min}$. The gel was visualized on a UV transilluminator for analysis of the cleavage of the treated DNA sample by using untreated DNA as a control and a marker was used to examine the molecular weight. All the experiments were carried out in triplicate under the same conditions.

\section{Conclusion}

The present study describes the synthesis of 4-[(4,5-dihydro-1,3thiazol-2-ylthio)methyl]substituted- $2 H$-chromen-2-one derivatives (1a-1j) under microwave irradiation which gives excellent yields in a shorter reaction time as compared to the conventional method. The most noticeable advancement in the present study is the speed at which the reaction was completed i.e. 5-9 minutes, which was 90-120 times faster than the conventional method. Single X-ray crystals of compounds 1a, 1b, 1e and $\mathbf{1 h}$ were developed and their crystal parameters were evaluated, which can contribute to the understanding of the reactivity, affinity and binding properties of the molecules. Antitubercular activity screening revealed that compound 6-chloro4-[(4,5-dihydro-1,3-thiazol-2-ylthio)methyl]-2H-chromen-2-one (1b) was found to be the most active in vitro, with a MIC of 0.09 $\mu \mathrm{g} \mathrm{ml} \mathrm{m}^{-1}$, and it exhibited a low level of cytotoxicity against Vero cells, which suggests that compound $\mathbf{1 b}$ can act as promising lead for the development of new anti-tubercular agents. Furthermore, compounds $\mathbf{1 b}$ and $\mathbf{1 i}$ which were found to be the most active in vitro against the $\mathrm{MtbH}_{3}$ strain were found to cleave DNA completely, which further confirmed that 
compounds $\mathbf{1 b}$ and $\mathbf{1 i}$ are biologically more potent in vitro agents. The obtained results suggest that the potent compounds may serve as lead chemical entities for further modification in the search for new classes of potential antitubercular drugs.

\section{Acknowledgements}

This research work is financially supported by the UGC, New Delhi under the UPE-FAR-I program, F. no. 14-3/2012 (NS/PE) and the Council of Scientific \& Industrial Research (CSIR), New Delhi - 110012 under reference no. 5496/NS/EMR-II/2015. The authors thank USIC, Karnatak University Dharwad, for providing spectral and X-ray analysis. We are also grateful to the NMR Research Centre, Indian Institute of Science (IISc), Bengaluru, India for the recording of the ${ }^{1} \mathrm{H}$ and ${ }^{13} \mathrm{C}$ NMR spectra.

\section{References}

1 (a) J. D. Bos and M. M. H. M. Meinardi, Exp. Dermatol., 2000, 9, 165-169; (b) D. F. Veber, S. R. Johnson, H. Y. Cheng, B. R. Smith, K. W. Ward and K. D. Kopple, J. Med. Chem., 2002, 45, 2615-2623.

2 C. A. Lipinski, F. Lombardo, B. W. Dominy and P. J. Feeney, Adv. Drug Delivery Rev., 1997, 23, 3-25.

3 (a) C. A. Lipinski, Drug Discovery Today: Technol., 2004, 1, 337-341; (b) P. D. Leeson and B. Springthorpe, Nat. Rev. Drug Discovery, 2007, 6, 881-890.

4 (a) X. M. Peng, G. L. V. Damu and C. H. Zhou, Curr. Pharm. Des., 2013, 19, 3884-3930; (b) S. H. Bairagi, P. P. Salaskar, S. D. Loke, N. N. Surve, D. V. Tandel and M. D. Dusara, Int. J. Pharm. Res., 2012, 4, 16-19; (c) C. Kontogiorgis, A. Detsi and D. Hadjipavlou-Litina, Expert Opin. Ther. Pat., 2012, 22, 437-454; (d) S. Mirunalini and M. Krishnaveni, Int. J. PharmTech Res., 2011, 3, 1693-1696.

5 (a) S. A. Stanley, T. Kawate, N. Iwase, M. Shimizu, A. Clatworthy, E. Kazyanskaya, J. C. Sacchettini, T. R. Ioerger, N. Siddiqi, S. Minami, J. A. Aquadro, S. S. Grant, E. J. Rubin and D. T. Hung, Proc. Natl. Acad. Sci. U. S. A., 2013, 110, 11565-11570; (b) M. Jeyachandran, P. Ramesh, D. Sriram, P. Senthilkumar and P. Yogeeswari, Bioorg. Med. Chem. Lett., 2012, 22, 4807-4809; (c) M. Basanagouda, V. B. Jambagi, N. N. Barigidad, S. S. Laxmeshwar and V. Devaru Narayanachar, Eur. J. Med. Chem., 2014, 74, 225-233; (d) I. Ahmad, J. P. Thakur, D. Chanda, D. Saikia, F. Khan, S. Dixit, A. Kumar, R. Konwar, A. S. Negi and A. Gupta, Bioorg. Med. Chem. Lett., 2013, 23, 1322-1325.

6 (a) T. Kawate, N. Iwase, M. Shimizu, S. A. Stanley, S. Wellington, E. Kazyanskaya and D. T. Hung, Bioorg. Med. Chem. Lett., 2013, 23, 6052-6059; (b) J. S. Mossa, E. Feraly and I. Muhammad, Phytother. Res., 2004, 18, 934-937; (c) G. Appendino, E. Mercalli, N. Fuzzati, L. Arnoldi, M. Stavri, S. Gibbons, M. Ballero and A. Maxia, J. Nat. Prod., 2004, 67, 2108-2110; (d) M. Figueroa, R. I. Cruz, R. B. Cruz, R. Byeb, A. Navarrete and R. Mata, J. Ethnopharmacol., 2007, 113, 125-131; (e) C. C. Chiang, M. J. Cheng, C. F. Peng,
H. Y. Huang and I. S. Chen, Chem. Biodiversity, 2010, 7, 1728-1736.

7 (a) P. Wipf, Chem. Rev., 1995, 95, 2115-2134; (b) B. S. Davidson, Chem. Rev., 1993, 93, 1771-1791.

8 (a) H. Luesch, W. A. Yoshida, R. E. Moore, V. J. Paul and T. H. Corbett, J. Am. Chem. Soc., 2001, 123, 5418-5423; (b) H. Luesch, W. A. Yoshida, R. E. Moore and V. J. Paul, Bioorg. Med. Chem., 2002, 10, 1973-1978.

9 C. J. Hawkins, M. F. Lavin, K. A. Marshall, A. L. van den Brenk and D. J. Watters, J. Med. Chem., 1990, 33, 1634-1638.

10 (a) W. Konigsberg, R. J. Hill and L. C. Craig, J. Org. Chem., 1961, 26, 3867-3871; (b) K. Yonetani, Y. Hirotsu and T. Shiba, Bull. Chem. Soc. Jpn., 1975, 48, 3302-3305.

11 A. C. Gaumont, M. Gulea and J. Levillain, Chem. Rev., 2009, 109, 1371-1401.

12 E. Pontiki, D. Hadjipavlou-Litina, A. T. Chaviarab and C. A. Bolosb, Bioorg. Med. Chem. Lett., 2006, 16, 2234-2237.

13 P. Wipf and P. C. Fritch, Tetrahedron Lett., 1994, 35, 53975400.

14 R. J. Boyce, G. C. Mulqueen and G. Pattende, Tetrahedron Lett., 1994, 35, 5705-5708.

15 S. D. Sharrow, M. V. Novotny and M. J. Stone, Biochemistry, 2003, 42, 6302-6309.

16 J. Y. Lai, J. Yu, B. Mekonnen and J. R. Falck, Tetrahedron Lett., 1996, 37, 7167-7170.

17 (a) K. Kumazawa, Food Sci. Technol. Res., 2006, 12, 71-84; (b) A. Adams and N. De Kimpe, Chem. Rev., 2006, 106, 22992313.

18 (a) H. Fujimoto, T. Kinoshita, H. Suzuki and H. Umezawa, J. Antibiot., 1970, 23, 271-275; (b) S. Pestka and N. Brot, J. Biol. Chem., 1971, 246, 7715-7722; (c) D. J. W. Burns, Eur. J. Biochem., 1973, 37, 570-574; (d) A. Ino and A. Murabayashi, Tetrahedron, 1999, 55, 10271-10282; (e) L. C. Craig, W. F. Phillips and M. Burachik, Biochemistry, 1969, 8, 2348-2356; $(f)$ H. Yamaguchi, Y. Nakayama, K. Takeda, K. Tawara, K. Maeda, T. Takeuchi and H. Umezawa, J. Antibiot., 1957, 10, 195-200.

19 (a) S. Vilar, E. Quezada, L. Santana, E. Uriarte, M. Yanez, N. Fraiz, C. Alcaide, E. Cano and F. Orallo, Bioorg. Med. Chem. Lett., 2006, 16, 257-261; (b) S. S. Xie, X. Wang, N. Jiang, W. Yu, K. D. G. Wang, J. S. Lan, Z. R. Li and L. Y. Kong, Eur. J. Med. Chem., 2015, 95, 153-165; (c) R. Gondru, J. Banothu, R. K. Thatipamula, S. K. Althaf Hussain and R. Bavantula, RSC Adv., 2015, 5, 33562-33569; (d) J. Zhao, H. Zhao, J. A. Hall, D. Brown, E. Brandes, J. Bazzill, P. T. Grogan, C. Subramanian, G. Vielhauer, M. S. Cohen and B. S. J. Blagg, Med. Chem. Commun., 2014, 5, 1317-1323; (e) S. V. Rodriguez, R. F. Guíñez, M. J. Matos, L. Santana, E. Uriarte, M. Lapier, J. D. Maya and C. OleaAzar, Med. Chem. Commun., 2013, 4, 993-1000; (f) K. M. Hosamani, D. S. Reddy and H. C. Devarajegowda, RSC Adv., 2015, 5, 11261-11271.

20 S. Sandhu, Y. Bansal, O. Silakari and G. Bansal, Bioorg. Med. Chem., 2014, 22, 3806-3814.

21 R. Forest and W. Jimmy, Org. Lett., 2010, 12, 2668-2671.

22 (a) J. Arunakaran, A. Arunkumar, M. Vijayababu, P. Venkataraman and K. Senthilkumar, Biol. Pharm. Bull., 
2006, 29, 375-379; (b) M. J. Wargovich, C. Woods, V. W. Eng, L. C. Stephens and K. Gray, Cancer Res., 1988, 48, 6872-6875; (c) M. J. Wargovich and H. Sumiyoshi, Cancer Res., 1990, 50, 5084-5087; (d) Y. Shukla, A. Arora and I. Siddiqui, Mol. Cancer Ther., 2004, 3, 1459-1466; (e) C. Yang, S. Chhabra, J. Hong and T. Smith, J. Nutr., 2001, 131, 1041S-1045S; $(f)$ T. Ariga and T. Seki, BioFactors, 2006, 26, 93-103; $(g)$ Y. Surh, R. Lee, K. Park, S. Mayne, A. Liem and J. Miller, Carcinogenesis, 1995, 16, 2467-2471.

23 M. J. Wargovich, J. Nutr., 2006, 136, 832S-834S.

24 (a) G. Liu, J. R. Huth, E. T. Olejniczak, R. P. Mendoza, S. DeVries, E. B. Reilly, G. F. Okasinski, E. Nielsen, S. W. Fesik and T. W. Geldern, J. Med. Chem., 2001, 44, 1202-1210; (b) S. F. Nielsen, E. O. Nielsen, G. M. Olsen, T. Liljefors and D. Peters, J. Med. Chem., 2000, 43, 2217-2226.

25 R. Brimblecombe, W. Duncan, G. Durant, J. Emmett, C. Ganellin and M. Parsons, J. Int. Med. Res., 1975, 3, 86-92.

26 J. M. Howard, A. N. Chremos, M. J. Collen, K. E. McArthur, J. A. Cherner, P. N. Maton, C. A. Ciarleglio, M. J. Cornelius, J. D. Gardner and R. T. Jensen, Gastroenterology, 1985, 88, 1026-1033.

27 J. Bradshaw, R. T. Brittain, J. W. Clitherow, M. J. Daly, D. Jack, B. J. Price and R. Stables, Br. J. Pharmacol., 1979, 66, 464P.

28 P. Trail, D. Willner, S. Lasch, A. Henderson, S. Hofstead, A. Casazza, R. Firestone, I. Hellstrom and K. Hellstrom, Science, 1993, 261, 212-215.

29 K. J. Shin, K. D. Koo, K. H. Yoo, Y. K. Kang, S. W. Park and D. J. Kim, Bioorg. Med. Chem. Lett., 2001, 11, 2397-2399.

30 R. S. Keri, K. M. Hosamani, H. S. Reddy and R. V. Shingalapur, Catal.Lett., 2009, 131, 552-559.

31 M. V. Kulkarni, B. J. Pujar and V. D. Patil, Arch. Pharm., 1983, 316, 15-21.

32 G. M. Sheldrick, SHELX97 Program for Crystallography Refinement, University of Göttingen, Germany, 1997.
33 S. G. Franzblau, R. S. Witzig, J. C. McLaughlin, P. Torres, G. Madico, A. Hernandez, M. T. Degnan, M. B. Cook, V. K. Quenzer, R. M. Ferguson and R. H. Gilman, J. Clin. Microbiol., 1998, 36, 362-366.

34 T. A. Brown, Essential Molecular Biology: A Practical Approach, Oxford University Press, 1990, vol. 1, p. 51.

35 K. Falzari, Z. Zhu, D. Pan, H. Liu, P. Hongmanee and S. G. Franzblau, Antimicrob. Agents Chemother., 2005, 49, 1447-1454.

36 K. P. Barot, S. V. Jain, N. Gupta, L. Kremer, S. Singh, V. B. Takale, K. Joshi and M. D. Ghate, Eur. J. Med. Chem., 2014, 83, 245-255.

37 (a) V. B. Jadhav, S. K. Nayak, T. N. Guru Rowb and M. V. Kulkarni, Eur. J. Med. Chem., 2010, 45, 3575-3580; (b) M. Ghate, R. A. Kusanur and M. V. Kulkarni, Eur. J. Med. Chem., 2005, 40, 882-887; (c) H. M. Revankar, M. V. Kulkarni, S. D. Joshi and U. A. More, Eur. J. Med. Chem., 2013, 70, 750-757.

38 (a) M. J. G. Fernandes, M. S. T. Goncalves and S. P. G. Costa, Tetrahedron, 2008, 64, 3032-3038; (b) M. J. G. Fernandes, M. S. T. Goncalves and S. P. G. Costa, Tetrahedron, 2008, 64, 11175-11179; (c) A. M. Soares, S. P. Costa and M. S. Goncalves, Amino Acids, 2010, 39, 121-133; (d) M. J. G. Fernandes, S. P. G. Costa and M. S. T. Goncalves, Tetrahedron, 2011, 67, 2422-2426.

39 (a) C. Tablet and M. Hillebrand, J. Photochem. Photobiol., A, 2007, 189, 73-79; (b) J. A. Key, S. Koh, Q. K. Timerghazin, A. Brown and C. W. Cairo, Dyes Pigm., 2009, 82, 196-203.

$40 \mathrm{G}$. Thomas, Medicinal Chemistry an Introduction, John Wiley \& Sons, West Sussex, UK, 2000.

41 S. Sreelatha, P. R. Padma and M. Umadevi, Food Chem. Toxicol., 2009, 47, 702-708.

42 V. Kumar, K. Kaur, D. N. Karelia, V. Beniwal, G. K. Gupta, A. K. Sharma and A. K. Gupta, Eur. J. Med. Chem., 2014, 81, 267-276. 